\title{
D-AREA TREATMENT TRENCH (DTT-1) EVALUATION (U)
}

March 31, 2003

\author{
M. A. Phifer \\ F. C. Sappington \\ M. R. Millings \\ C. E. Turick \\ P. McKinsey
}

UNCLASSIFIED
Does Not Contain Unclassified Nuclear Information (UCNI)

Westinghouse Savannah River Company

Savannah River Site

Aiken, SC 29801

Prepared for the US Department of Energy under Contract DE-AC09-96SR18500 
This document was prepared in conjunction with work accomplished under Contract No. DE-AC09-96SR18500 with the U. S. Department of Energy.

\section{DISCLAIMER}

This report was prepared as an account of work sponsored by an agency of the United States Government. Neither the United States Government nor any agency thereof, nor any of their employees, makes any warranty, express or implied, or assumes any legal liability or responsibility for the accuracy, completeness, or usefulness of any information, apparatus, product or process disclosed, or represents that its use would not infringe privately owned rights. Reference herein to any specific commercial product, process or service by trade name, trademark, manufacturer, or otherwise does not necessarily constitute or imply its endorsement, recommendation, or favoring by the United States Government or any agency thereof. The views and opinions of authors expressed herein do not necessarily state or reflect those of the United States Government or any agency thereof.

This report has been reproduced directly from the best available copy.

Available for sale to the public, in paper, from: U.S. Department of Commerce, National Technical Information Service, 5285 Port Royal Road, Springfield, VA 22161, phone: (800) 553-6847, fax: (703) 605-6900

email: orders@ntis.fedworld.gov

online ordering: http://www.ntis.gov/help/index.asp

Available electronically at http://www.osti.gov/bridge

Available for a processing fee to U.S. Department of Energy and its contractors, in paper, from: U.S. Department of Energy, Office of Scientific and Technical Information, P.O. Box 62, Oak Ridge, TN 37831-0062,

phone: (865)576-8401,

fax: (865)576-5728

email: $\underline{\text { reports@ adonis.osti.gov }}$ 


\section{D-AREA TREATMENT TRENCH (DTT-1) EVALUATION}

\subsection{EXECUTIVE SUMMARY}

A limestone trench was installed adjacent to the D-Area Coal Pile Runoff Basin (DCPRB) on May 4, 1999. Since limestone is considered the most likely amendment to produce the optimal $\mathrm{pH}$ range for sulfate reduction in the D-Area low $\mathrm{pH} / \mathrm{metals} /$ sulfate plume (Phifer, et al. 2001), the existing limestone trench has undergone a re-evaluation. The re-evaluation has been conducted to determine if the hydraulic and geochemical activity of the limestone trench is similar to its initial conditions upon installation and to determine the potential to promote sulfate reduction at the limestone trench with the addition of an organic carbon substrate.

The results of the re-evaluation indicate that the limestone trench is essentially as hydraulically active now as it was at its installation. Additionally it has been determined that the limestone trench remains an effective treatment for increasing the $\mathrm{pH}$ and removing aluminum as at its installation. Finally it has been determined that the limestone trench has increased sulfate reducing bacteria (SRB) activity and has in general improved conditions relative to optimal sulfate reduction conditions. Based upon this re-evaluation it has been determined that limestone could potentially be a viable component of an in-situ sulfate reduction remediation system, and the addition of soybean oil downgradient of the limestone trench should result in successful sulfate reduction remediation. 
Table of Contents

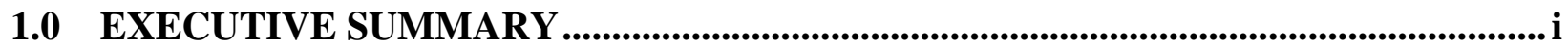

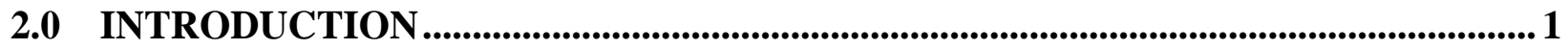

3.0 D-AREA TREATMENT TRENCH (DTT-1) BACKGROUND INFORMATION ....... 2

4.0 DTT-1 HYDRAULIC EVALUATION.......................................................................8 8

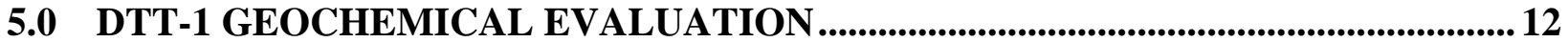

6.0 DTT-1 SULFATE REDUCTION POTENTIAL EVALUATION .................................. 22

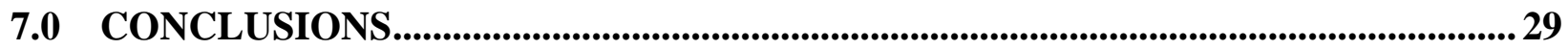

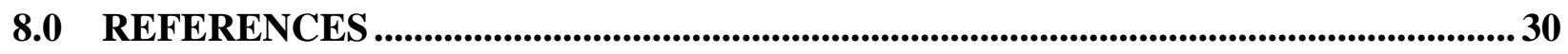

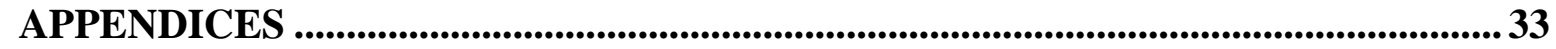

List of Tables

Table 1. DTT-1, DCB-49, and DCB-50 Details.................................................................3

Table 2. 1999 Limestone Trench (DTT-1) Specific Capacity ................................................. 10

Table 3. 2002 Limestone Trench (DTT-1) Specific Capacity .................................................... 11

Table 4. DCB-50 Aluminum and pH Concentrations.............................................................22

Table 5. Microbial Parameters.............................................................................................................. 27

Table 6. Limestone Trench Conditions Versus Optimal Sulfate Reduction Conditions...... 28

Table 7. D-Area Interceptor Well (DIW-1) Versus Limestone Trench Conditions.............. 29

\section{List of Figures}

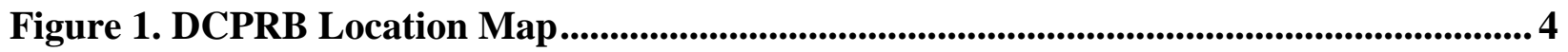

Figure 2. DTT-1 and Adjacent Monitoring Wells Location Map............................................... 5

Figure 3. DTT-1 Plan View (Washburn et al. 1999) ......................................................6 6

Figure 4. DTT-1 Cross-Section (Washburn et al. 1999) ............................................................... 7

Figure 5. 2002 Data Measurement Summary ....................................................................... 10

Figure 6. 1999 to 2002 Specific Capacity Comparison .................................................................. 12

Figure 7. Field Measurement Profiles and Collected Samples................................................... 18

Figure 8. DCB-49 and DTT-1 Calcium Versus Magnesium Concentrations .......................... 19

Figure 9. DTT-1 Post Pump Tests Calcium Versus Magnesium Concentrations .................. 19

Figure 10. DCB-50 Calcium Versus Magnesium Concentrations ........................................20

Figure 11. DCB-49 Calcium Versus Aluminum Concentrations ............................................. 20

Figure 12. Method of Calculation of Calcium and Magnesium Concentrations in

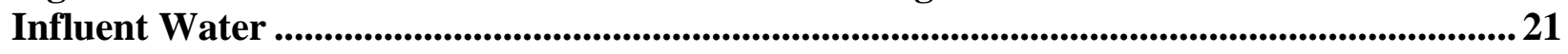

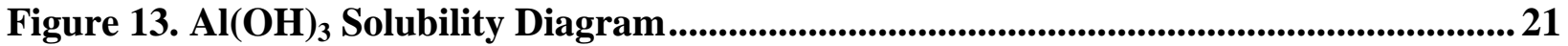




\section{List of Abbreviations}

BHS $=$ bottom horizontal screen

bls $=$ below land surface

BOS $=$ bottom of vertical screen

$\mathrm{cfs} / \mathrm{ft}=$ specific capacity measured in cubic feet per second per foot

DCPRB = D-Area Coal Pile Runoff Basin

DIW-1 = D-Area Interceptor Well

$\mathrm{DO}=$ dissolved oxygen

DTT-1 = D-Area Treatment Trench

EBS $=$ Environmental Biotechnology Section

$\mathrm{Eh}=$ redox potential

$\mathrm{EPA}=$ United States Environmental Protection Department

$\mathrm{ft}=$ feet

$\mathrm{ft}-\mathrm{msl}=$ feet above mean sea level

gpm $=$ gallons per minute

$\mathrm{gpm} / \mathrm{ft}=$ specific capacity measured in gallons per minute per foot

$\mathrm{IC}=$ Ion Chromatography

ICP-AES = Inductively Coupled Plasma - Atomic Emission Spectroscopy

$\mathrm{mg} / \mathrm{L}=$ milligram per liter

$\mathrm{ml}=$ milliliter

$\mathrm{mV}=$ millivolt

$\mathrm{PVC}=$ polyvinyl chloride

$\mathrm{SRB}=$ sulfate-reducing bacteria

SRTC = Savannah River Technology Center

THS $=$ top horizontal screen

TOC $=$ top of casing

TOC $=$ total organic Carbon

TOS $=$ top of vertical screen

$\mu \mathrm{g} / \mathrm{L}=$ microgram per liter

$\mu \mathrm{S} / \mathrm{cm}=$ microSiemens per centimeter

WSRC $=$ Westinghouse Savannah River Company

$\mathrm{XRD}=\mathrm{x}$-ray diffraction

$\mathrm{XRF}=\mathrm{x}$-ray fluorescence 


\section{D-AREA TREATMENT TRENCH (DTT-1) EVALUATION}

\subsection{INTRODUCTION}

A low $\mathrm{pH} / \mathrm{metals} / \mathrm{sulfate}$, groundwater contaminant plume emanates from the D-Area Coal Pile Runoff Basin (DCPRB), due to the contaminated runoff the basin receives from the D-Area coal pile. A field study, to assess the potential of in situ sulfate reduction to serve as a remedial technology for this groundwater plume, is currently being conducted (WSRC 2001; Phifer et al. 2002a). In situ sulfate reduction entails the oxidation of an organic substrate by sulfate-reducing bacteria (SRB) for energy and growth, the use of sulfate as the terminal electron acceptor, the production of carbonates and hydrogen sulfide, an increase in $\mathrm{pH}$, a decrease in Eh, and the

precipitation of metal sulfides, hydroxides and carbonates. In addition to the need to add organic carbon substrates to promote in situ sulfate reduction, the $\mathrm{pH}$ optimally needs to be in the range of 5.5 to 9 . (Phifer et al. 2001)

A limestone trench was installed as part of a Permeable Reactive Barrier/GeoSiphon treatment system that was evaluated for the treatment of metals contaminated groundwater (i.e. the D-Area low $\mathrm{pH} /$ metals/sulfate plume). The previous study is documented in Washburn et al. 1999. The limestone trench, D-Area Treatment Trench (DTT-1), is a $2 \mathrm{ft}$ wide by $40 \mathrm{ft}$ long by 15 to $16 \mathrm{ft}$ deep trench filled with limestone which was installed adjacent to DCPRB on May 4, 1999. Since limestone is considered the most likely amendment to produce the optimal $\mathrm{pH}$ range for sulfate reduction in the D-Area low $\mathrm{pH} /$ metals/sulfate plume (Phifer, et al. 2001), the existing limestone trench has undergone a re-evaluation. The re-evaluation has been conducted to determine if the hydraulic and geochemical activity of the limestone trench is similar to its initial conditions upon installation and to determine the potential to promote sulfate reduction at the limestone trench with the addition of an organic carbon substrate.

To address the hydraulic activity of the limestone trench, the current specific capacity of the trench has been determined and compared to that previously determined at the same flow rates (Washburn et al. 1999). To address the geochemical activity of the limestone trench, current parameters such as calcium, magnesium, aluminum, and $\mathrm{pH}$ have been determined and compared to that previously determined (Washburn et al. 1999). In particular a comparison of the current and previous hydraulic and geochemical activity of the trench will address the potential for 
limestone armoring and formation/limestone pluggage, which is directly related to limestone longevity within the D-Area low $\mathrm{pH} /$ metals/sulfate plume environment. To address the existing sulfate reduction potential that exists within the trench the existing microbial activity within the trench and trench conditions versus optimal sulfate reduction conditions and the current sulfate reduction field study have been evaluated. All work was conducted in conformance with the $D$ Area Treatment Trench (DTT-1) Evaluation Field Scoping Plan (Phifer et al., 2002b).

\subsection{D-AREA TREATMENT TRENCH (DTT-1) BACKGROUND INFORMATION}

The D-Area Treatment Trench (DTT-1) was permitted as a well and installed adjacent to the DArea Coal Pile Runoff Basin (DCPRB) on May 4, 1999. See Figures 1 and 2 for the location of DTT-1 relative to that of the DCPRB, and see Figures 3 and 4 for as-built diagrams of DTT-1. Table 1 and Figure 2 provide details associated with DTT-1 and adjacent monitoring wells, DCB-49 and DCB-50. The following description of DTT-1 is taken from Washburn et al. 1999:

"The trench design called for a 2 foot wide by 40 foot long by 16.5 foot deep trench, with about a 10 foot vertical saturated thickness. Within the trench, four-inch-diameter Schedule 40 PVC piping was configured in three vertical risers connected by two horizontal pipes spaced 4 feet apart. The northern most riser was designated DTT-1A; the center riser was designated DTT-1, and the southern most riser was designated DTT1B. One horizontal pipe was connected to the riser bottoms. A second horizontal pipe was connected to the risers about four feet above the bottom horizontal pipe. Both horizontal pipes had at least four rows of 3/8-inch diameter holes spaced about four inches apart to allow groundwater flow into the piping. All three risers extended to above the ground surface for access to the trench. The trench was backfilled around the piping with Number Four sized, limestone cobble aggregates. The center riser, DTT-1, transitioned from 4 inch polyvinyl chloride (PVC) to a 6 inch by 3 inch tee at approximately 2 feet bls, with the 6 inch piping extending to above the ground surface and with a 3 inch PVC siphon sleeve connecting to the tee. ..."

"The trench, subsurface piping, limestone-rock aggregate backfill, and the siphon sleeve were installed by Bechtel Savannah River, Inc. on May 4, 1999. The total as installed 
trench depth was approximately 15-16 feet below land surface (bls). The trench was excavated by backhoe, digging with a 2-foot-wide bucket. An approximate 1-2 foot layer of limestone aggregate was placed in the trench bottom. The piping system was placed atop the initial 1-2 foot layer of limestone, with the lower horizontal perforated piping set at about 14 feet bls. Limestone aggregate was then carefully placed around the piping system to a depth of about 2 feet bls. The trench was finished near the surface with two layers of non-woven geotextile material placed over the limestone rock aggregate backfill. The geotextile material was covered with native soil fill and mounded slightly to allow precipitation runoff and settling. ... Each of the three PVC risers was finished with a 4 foot by 4 foot by 6 -inch thick concrete pad and protective steel casing. ..."

Table 1. DTT-1, DCB-49, and DCB-50 Details

\begin{tabular}{|c|c|c|c|c|c|c|}
\hline \multirow{2}{*}{$\begin{array}{l}\text { Trench } \\
\text { Access }\end{array}$} & \multicolumn{2}{|c|}{ Coordinates $(\mathrm{ft})$} & \multirow{2}{*}{$\begin{array}{l}\text { Diameter } \\
\text { (inches) }\end{array}$} & \multicolumn{3}{|c|}{ Elevation (ft-msl) } \\
\hline & North & South & & TOC & THS & BHS \\
\hline DTT-1A & 63447.78 & 20000.97 & 4 & 124.7 & 112.47 & 108.47 \\
\hline DTT-1 & 63431.43 & 20007.49 & 4 & 122.64 & 112.47 & 108.47 \\
\hline DTT-1B & 63415.08 & 20014.68 & 4 & 124.72 & 112.47 & 108.47 \\
\hline \multirow[t]{2}{*}{ Well } & \multicolumn{2}{|c|}{ Coordinates $(\mathrm{ft})$} & Diameter & \multicolumn{3}{|c|}{ Elevation (ft-msl) } \\
\hline & North & South & (inches) & TOC & TOS & BOS \\
\hline DCB-49 & 63429.96 & 20013.93 & 2 & 124.52 & 118.67 & 106.17 \\
\hline DCB-50 & 63426.58 & 20004.29 & 2 & 124.33 & 118.29 & 105.73 \\
\hline
\end{tabular}

Notes to Table 1:

TOC $=$ top of casing; THS $=$ top horizontal screen; BHS = bottom horizontal screen; TOS $=$ top of vertical screen; BOS = bottom of vertical screen 


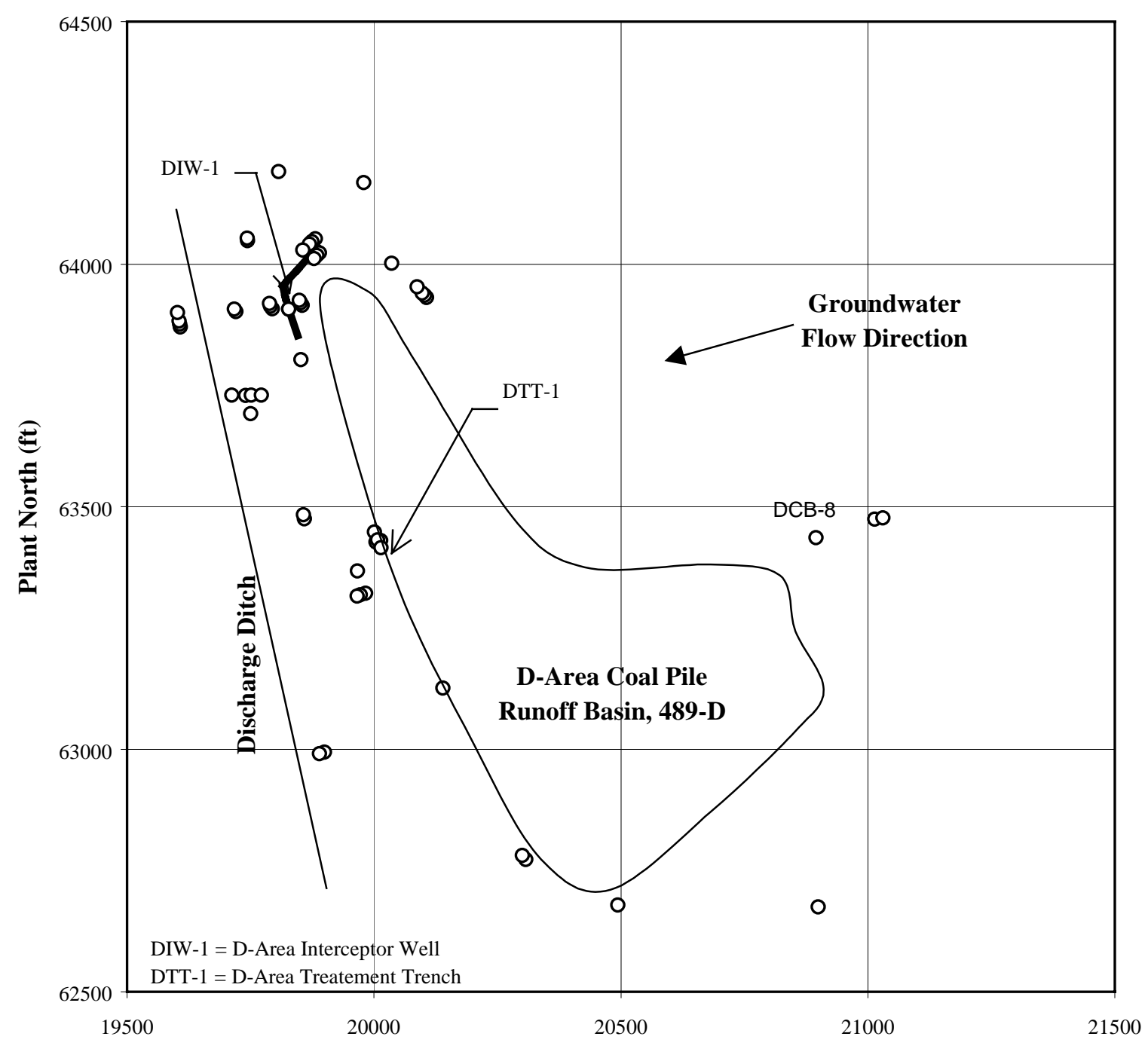

Plant East (ft)

Figure 1. DCPRB Location Map 


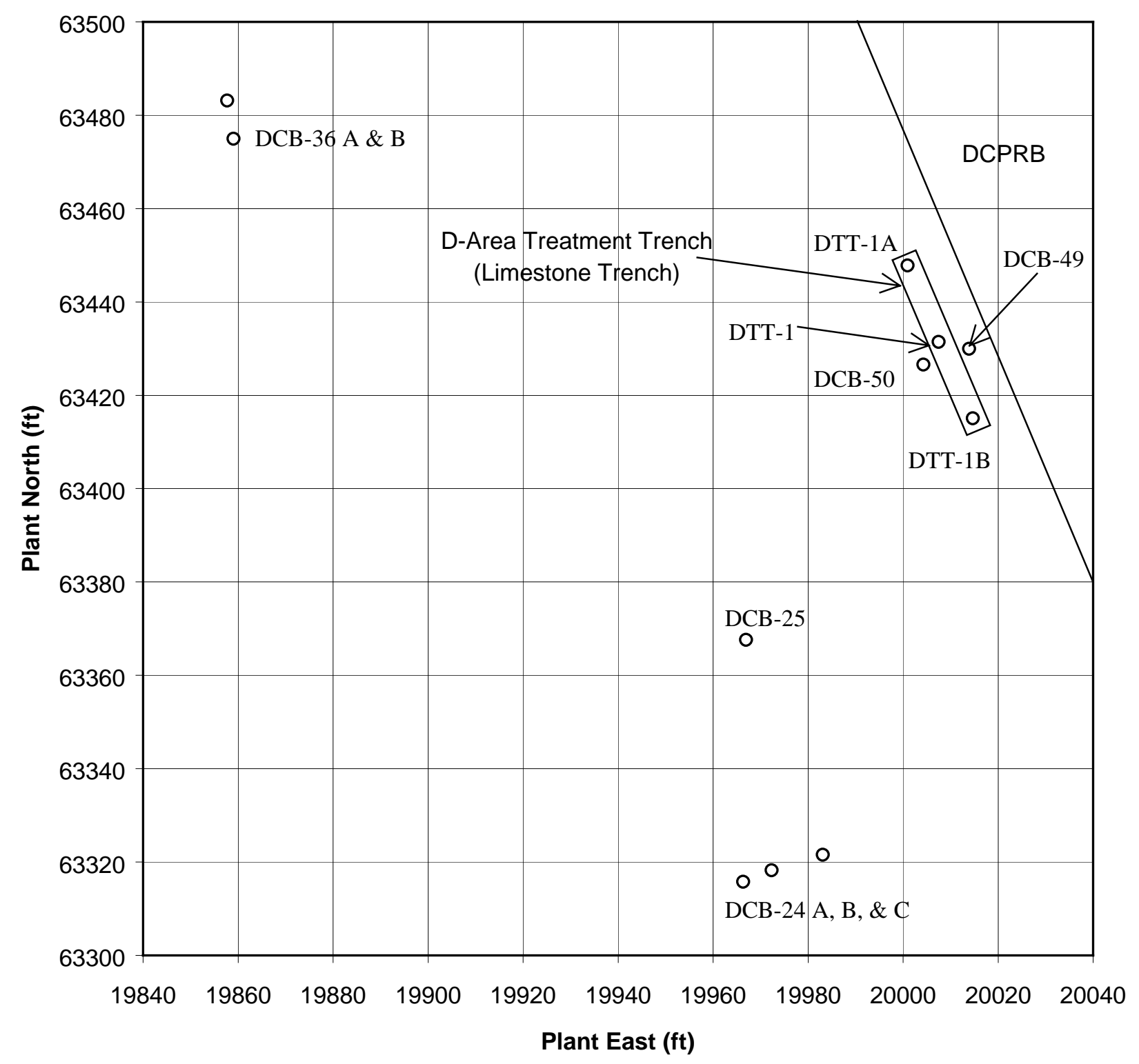

Figure 2. DTT-1 and Adjacent Monitoring Wells Location Map 


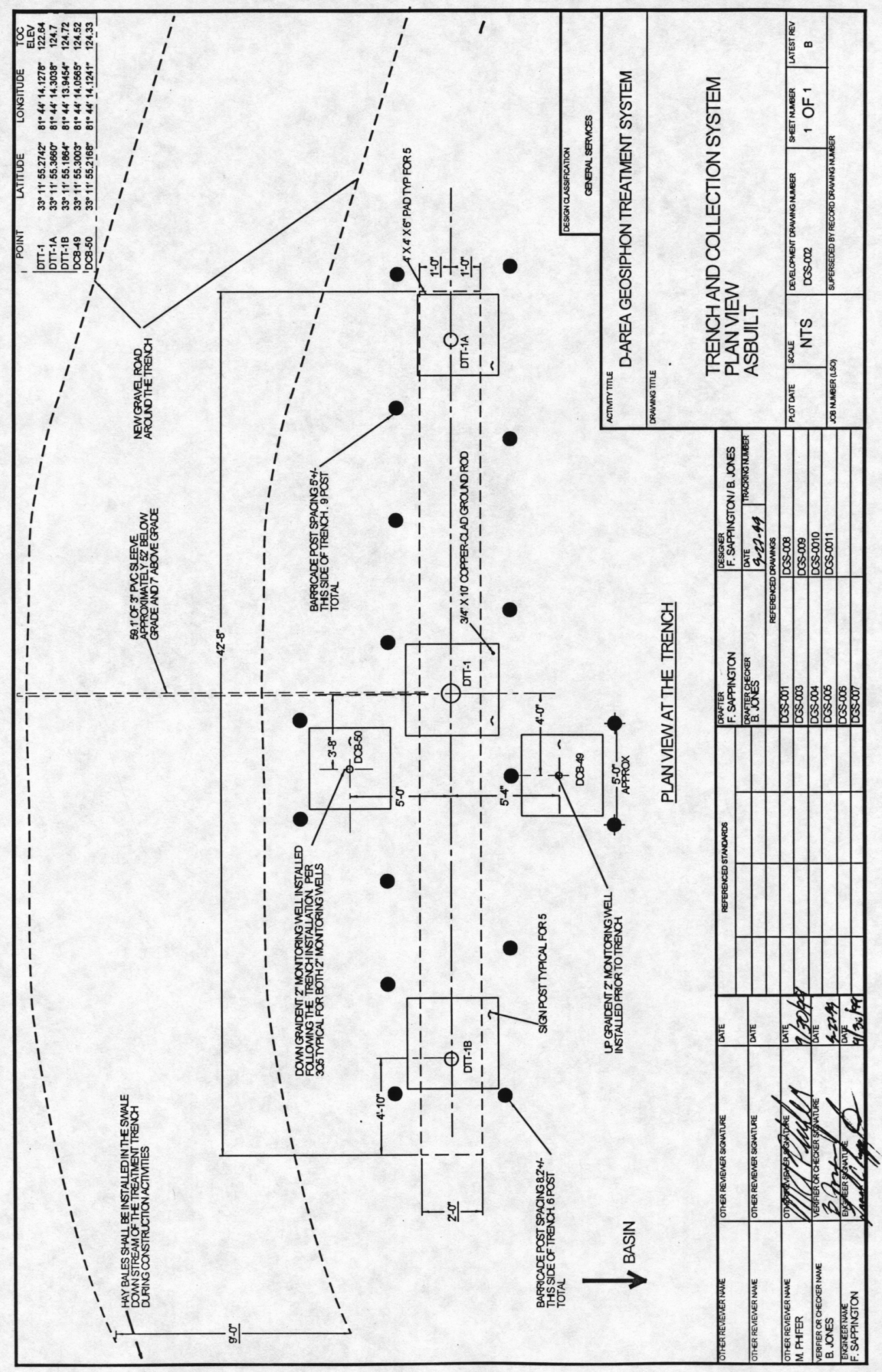

Figure 3. DTT-1 Plan View (Washburn et al. 1999) 


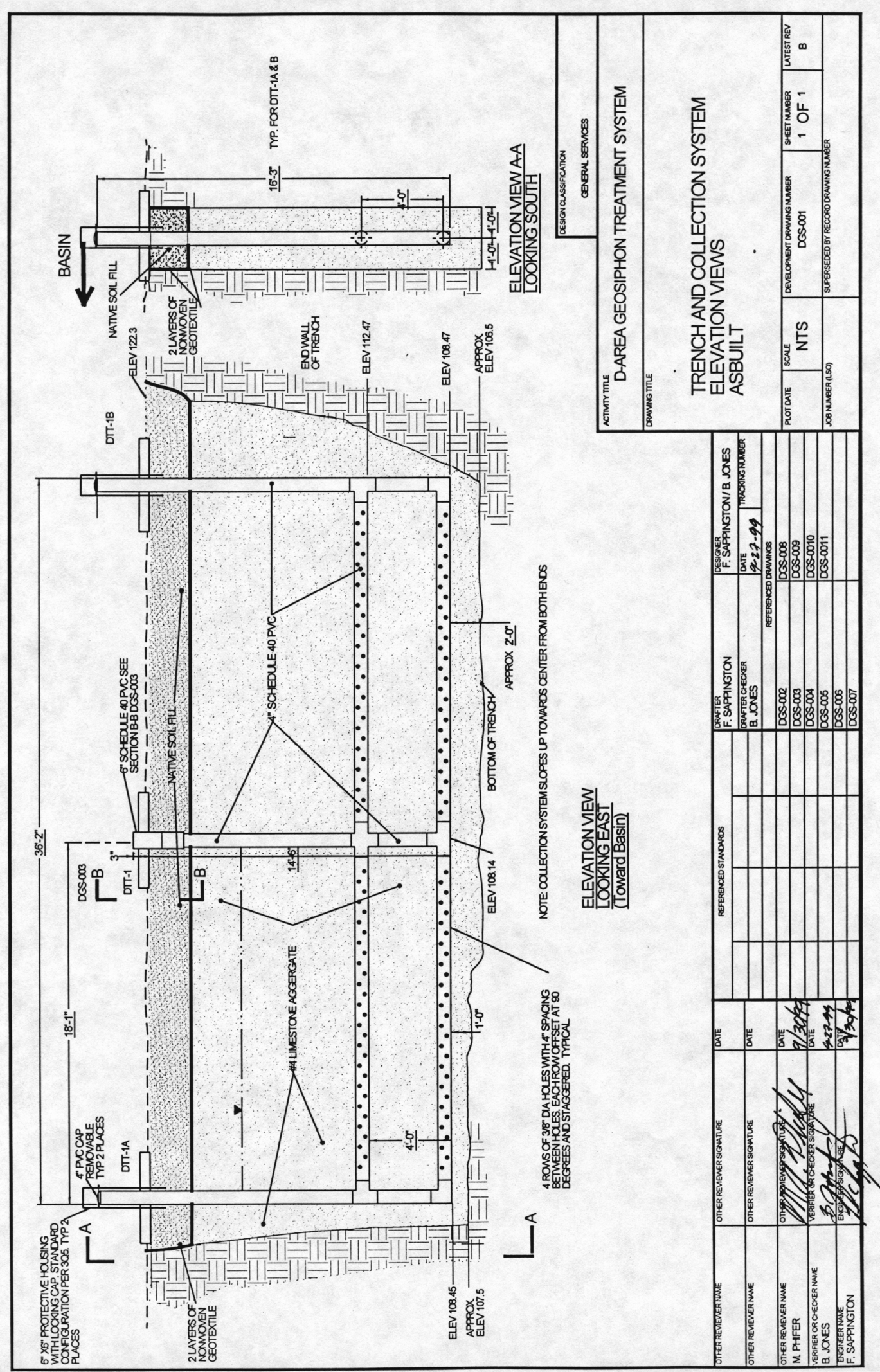

Figure 4. DTT-1 Cross-Section (Washburn et al. 1999) 


\subsection{DTT-1 HYDRAULIC EVALUATION}

The hydraulic activity of the limestone trench has been addressed by determining the current specific capacity of the trench and comparing it to that previously determined following its installation in 1999. Table 2 provides the 1999 specific capacity estimates. The 1999 estimated specific capacities ranged from 0.402 to $0.562 \mathrm{gpm} / \mathrm{ft}$ with an average and standard deviation of 0.562 and $0.054 \mathrm{gpm} / \mathrm{ft}$, respectively. (Washburn et al. 1999)

The current specific capacity estimates were obtained by pumping the trench, measuring drawdown and flow, and then calculating the specific capacity (flow rate divided by drawdown). Water level measurements, which were used to determine the drawdown, were taken continuously with pressure transducers and periodically with an electric water level tape. The periodic flow rate measurements were made using a known volume and stop watch. The current specific capacity estimates have been determined at approximately the same flow rates and durations since pumping began as those determined in 1999. The 1999 specific capacity estimates were made based upon flow rates ranging from approximately 0.4 to $1.2 \mathrm{gpm}$ taken at durations of approximately 24 and 48 hours since pumping began. For the current testing water level measurements began approximately four days prior to initiating pumping and continued through completion of pumping. Two pumping episodes were conducted during December 2002 at flows of approximately $0.5 \mathrm{gpm}$ and $1 \mathrm{gpm}$, respectively, with an approximately five-day recovery period in between. Additionally D-Area rainfall data for the testing period was also obtained. Figure 5 provides a summary of the 2002 data measured.

Data utilized to make the 2002 specific capacity estimates were obtained at approximately 24 and 48 hours since pumping began during periods like that of the 1999 estimates. The specific capacity data at these times was only utilized when the drawdown appeared to have stabilized as indicated by relatively constant elevations, rainfall did not appear to impact the water elevation, and the flow rate had not recently been adjusted (see Figure 5). The flow rates utilized to estimate the 2002 specific capacity are denoted by an " $\times$ " in Figure 5.

Table 3 presents the current specific capacity estimates based upon both drawdowns determined by electric water level tape (DTT-1) and pressure transducer (DTT-1B) measurements. The 
December 2002 specific capacity estimates consist of three measurements ranging from 0.431 to $0.506 \mathrm{gpm} / \mathrm{ft}$ with an average of $0.459 \mathrm{gpm} / \mathrm{ft}$ for estimates based upon electric water level tape measurements. The same estimates range from 0.450 to $0.523 \mathrm{gpm} / \mathrm{ft}$ with an average of 0.481 $\mathrm{gpm} / \mathrm{ft}$ for estimates based upon pressure transducer measurements. The estimates based upon pressure transducer measurements are on average 5\% higher than those based upon electric water level tape measurement. Appendices A-1 and A-2 provide the detailed flow measurements and water elevations as determined from electric water level tape measurements, respectively.

As seen in Table 2 the 1999 specific capacity estimates consist of ten measurements ranging from 0.402 to $0.562 \mathrm{gpm} / \mathrm{ft}$ with an average of $0.489 \mathrm{gpm} / \mathrm{ft}$ and a standard deviation of 0.054 gpm/ft. The 1999 specific capacity estimates were based upon DTT-1 drawdown determined only by electric water level tape. While the 2002 averages are slightly less than the 1999 average (by less than 7\%), the 2002 averages are based upon only three measurements versus ten in 1999. Additionally as seen in Figure 6 all of the 2002 data falls within the range of the 1999 data, and all but one of the 2002 data points lie within one standard deviation of the 1999 average. Therefore based upon this comparison it is concluded that little if any reduction in specific capacity has occurred between 1999 and 2002. That is the limestone trench appears to be essentially as hydraulically active now as it was at its installation. This indicates that precipitate accumulation has not significantly plugged the limestone or the formation. 
Table 2. 1999 Limestone Trench (DTT-1) Specific Capacity

\begin{tabular}{|c|c|c|c|}
\hline $\begin{array}{c}\text { Approximate } \\
\text { Duration Since } \\
\text { Pumping Began } \\
\text { (hours) }\end{array}$ & $\begin{array}{c}\text { Flow } \\
\text { (gpm) }\end{array}$ & $\begin{array}{c}\text { Specific Capacity } \\
\text { (gpm/ft) }\end{array}$ & $\begin{array}{c}\text { Specific Capacity } \\
\text { (cfs/ft) }\end{array}$ \\
\hline 53 & 0.40 & 0.407 & 0.00091 \\
\hline 47 & 0.41 & 0.466 & 0.00104 \\
\hline 26 & 0.44 & 0.562 & 0.00125 \\
\hline 24 & 0.58 & 0.521 & 0.00116 \\
\hline 47 & 0.65 & 0.500 & 0.00111 \\
\hline 25 & 0.69 & 0.552 & 0.00123 \\
\hline 50 & 1.03 & 0.481 & 0.00107 \\
\hline 24 & 1.14 & 0.402 & 0.00090 \\
\hline 48 & 1.14 & 0.487 & 0.00109 \\
\hline 25 & 1.17 & 0.515 & 0.00115 \\
\hline & Average & 0.489 & 0.00109 \\
\hline \multicolumn{2}{r|}{ Standard Deviation } & 0.054 & 0.00012 \\
\hline Average - One Standard Deviation & 0.436 & 0.00097 \\
\hline Average + One Standard Deviation & 0.543 & 0.00121 \\
\hline \multicolumn{2}{|r}{}
\end{tabular}

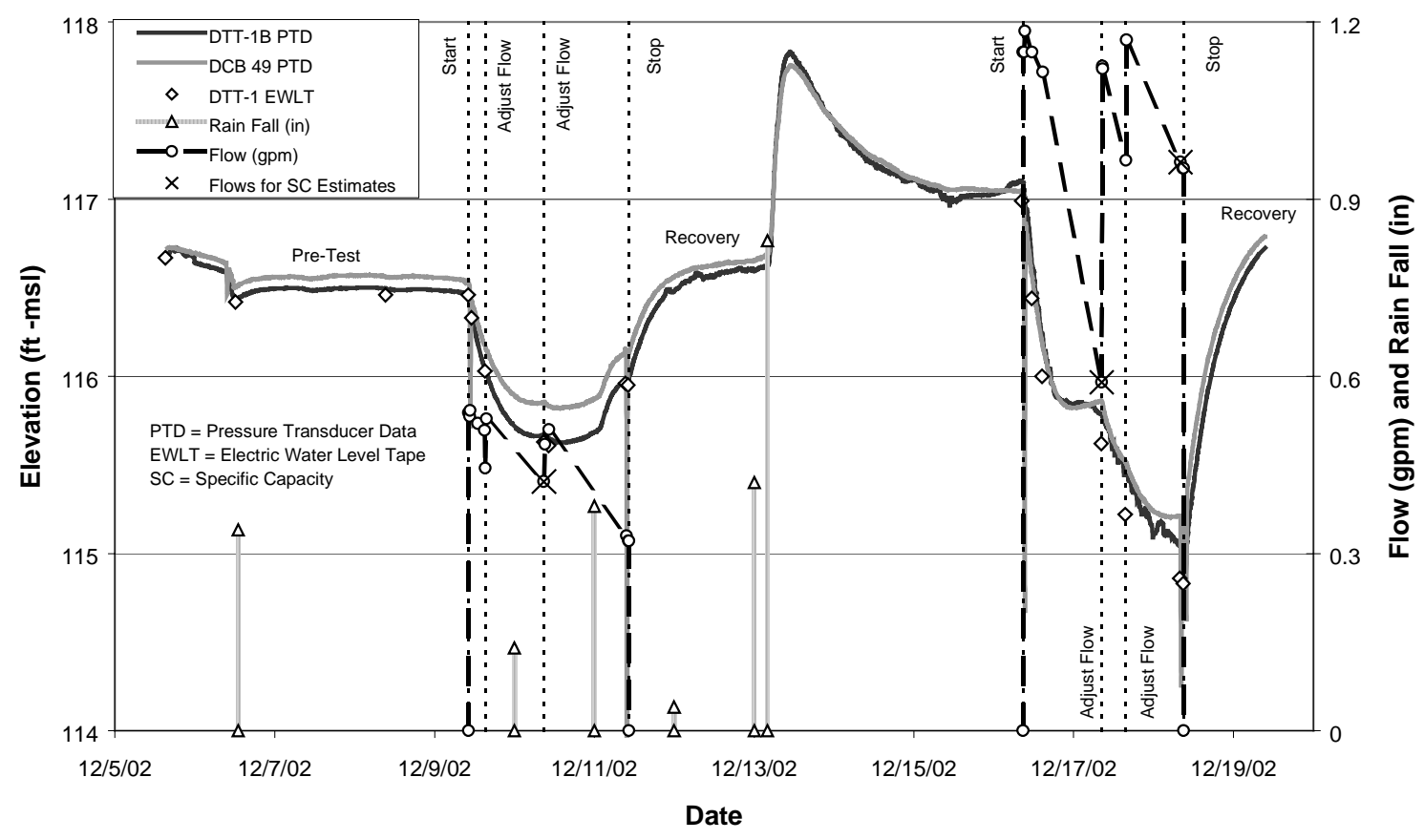

Figure 5. 2002 Data Measurement Summary 


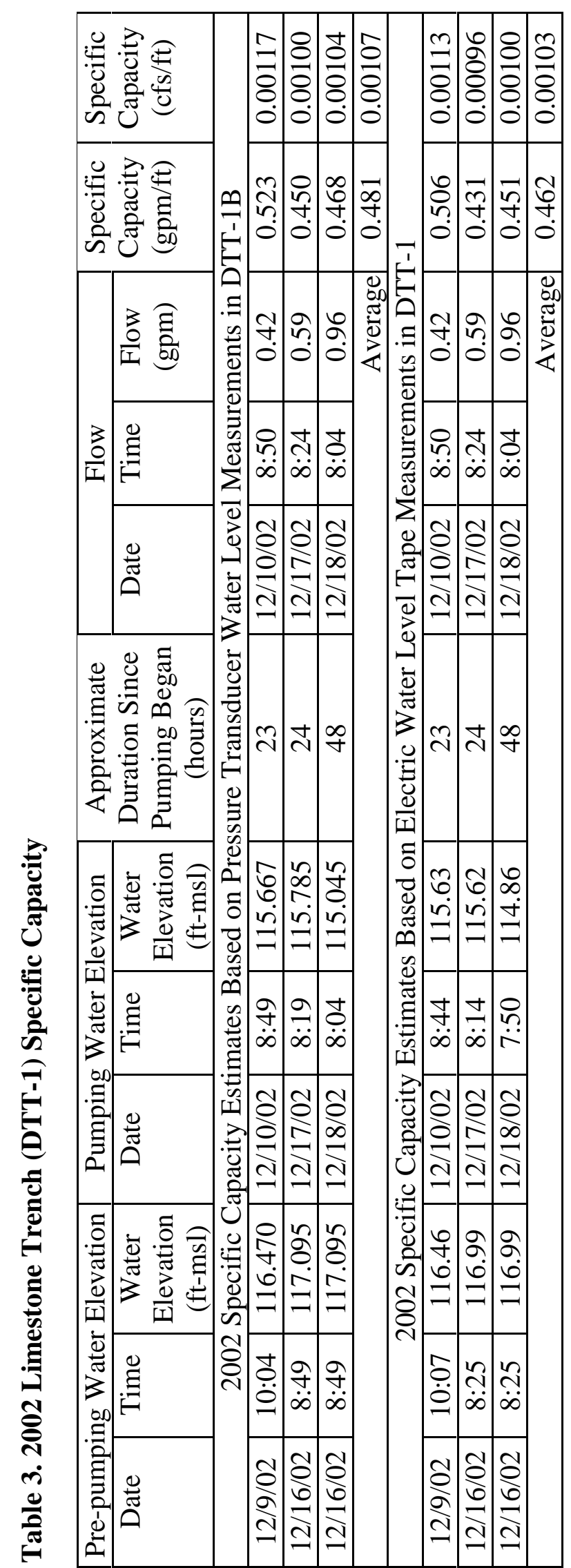




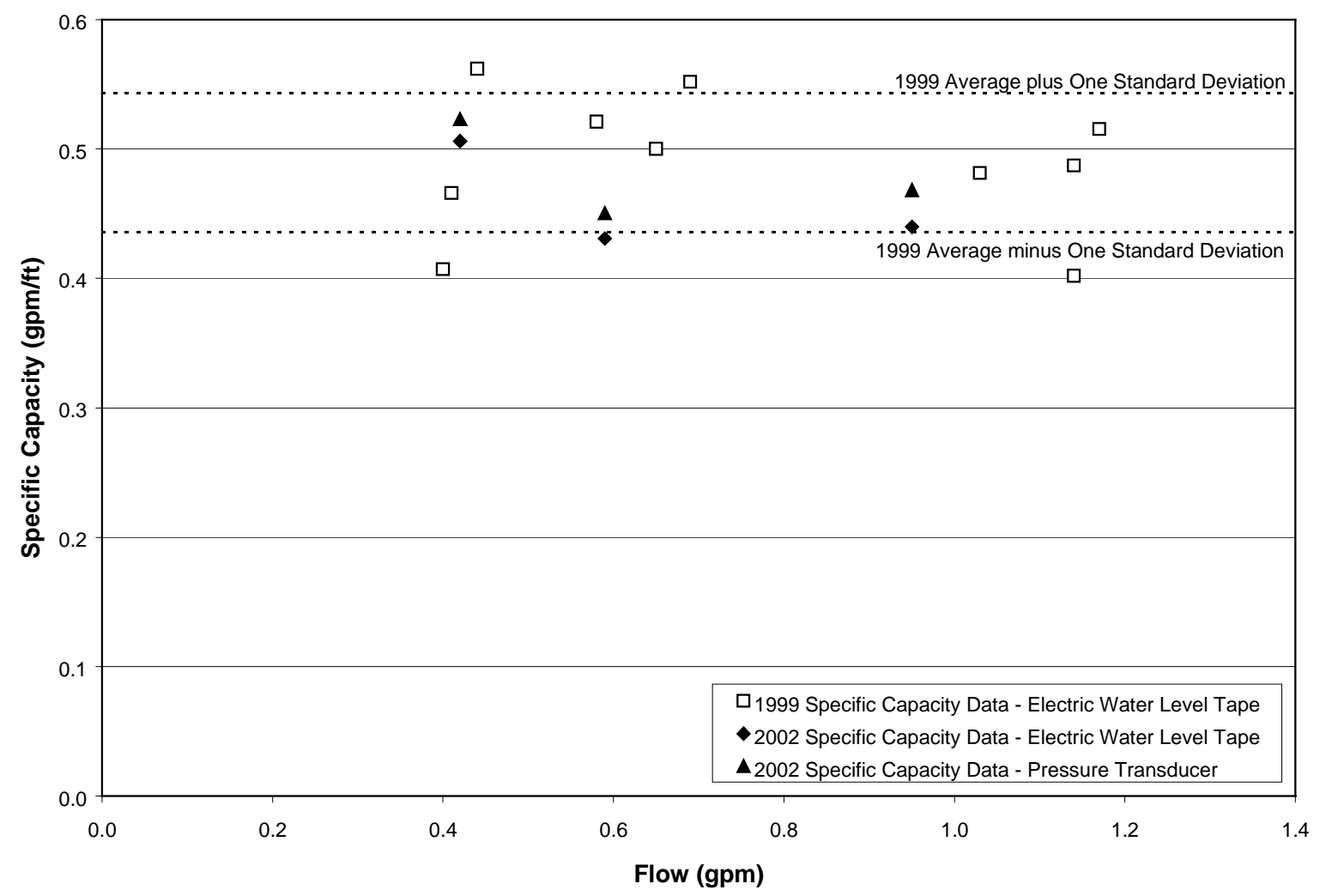

Figure 6. 1999 to 2002 Specific Capacity Comparison

\subsection{DTT-1 GEOCHEMICAL EVALUATION}

To address the geochemical activity of the limestone trench, current parameters such as calcium, magnesium, aluminum, and $\mathrm{pH}$ have been determined and compared to that previously determined (Washburn et al. 1999). As also discovered in the earlier study, the heterogeneity of the waters entering the trench makes it difficult to assess the magnitude of the effects of the limestone trench. However, relationships among chemical constituents together with field parameter profiles and samples provide information regarding influent waters, their interaction with the limestone trench and the impact on downgradient waters. Appendices B-1 through B-6 provide the detailed data utilized in this geochemical discussion. 


\section{Compositional Heterogeneity}

Field parameter profiles illustrate the compositional heterogeneity within DCB-49 and the trench (Figure 7). The upper six feet of the DCB-49 screen zone consists of waters with low conductivity $(<100 \mathrm{uS} / \mathrm{cm})$ and $\mathrm{pH}$ 's near 4 . In the bottom two feet of the screen zone, the $\mathrm{pH}$ drops to 3.2 and conductivity increases to $3000 \mathrm{uS} / \mathrm{cm}$ reflecting higher concentrations of dissolved ions (e.g. sulfate, aluminum, iron, hydrogen). This change in the DCB-49 profile suggests that the plume emanating from the basin is stratified, with the lower portion of DCB-49 reflecting a more contaminated part of the plume. Waters with differing geochemistries are also found within the limestone trench. The upper portion of the trench (elevation 112.5-115.5 feet) consists of relatively low conductivity $(500 \mathrm{uS} / \mathrm{cm}), \mathrm{pH}$ neutral waters. Additionally, collected samples have low concentrations of sulfate, aluminum, and iron (Appendix B-3). However, with depth the $\mathrm{pH}$ decreases to 4 and conductivity increases to $1500 \mathrm{uS} / \mathrm{cm}$. Collected samples have high concentrations of sulfate, aluminum, and ferrous iron. These findings are consistent with the stratification seen in the depth discrete samples collected in 1999, which showed that aluminum concentrations varied from $<2 \mathrm{mg} / \mathrm{L}$ to $135 \mathrm{mg} / \mathrm{L}$ and $\mathrm{pH}$ varied from 5.33 to 3.87 over a 2-foot interval (Washburn et al. 1999).

Discrepancies found between the field parameter profiles and the field measurements of the samples collected for elemental analysis (represented as circles on Figure 7) most likely reflect artifacts of sampling. Purge rates and volumes during sample collection may have caused waters with differing geochemistries to mix and resulted in the collection of waters that are not representative of the heterogeneity present. In particular, the lower samples collected in DTT-1 and DTT-1B had field measurements and elemental concentrations more similar to the water in the upper part of the trench than the bottom water of the trench. Similarly, the sample collected from DCB-49 had field measurements representative of its lower, more contaminated water. 


\section{Calcium and Magnesium Concentrations}

The relationship between calcium and magnesium concentrations is useful in evaluating the dissolution of limestone in the trench. In DCB-49 the concentrations of calcium and magnesium are linearly correlated and although their concentrations are higher than they were in 1999, their ratio is consistent with the ratio found in the earlier study (Figure 8). Limestone from the same batch as used in the trench was dissolved in acidic water and found to have a different ratio than that of DCB-49. More specifically, the dissolved limestone had a calcium concentration of $5.68 \mathrm{mg} / \mathrm{L}$ and a magnesium concentration of $0.69 \mathrm{mg} / \mathrm{L}$ (Washburn et al. 1999). This ratio can be used to plot the dissolution line of the limestone, which shows the calcium to magnesium ratio expected as limestone dissolves.

Samples collected from the trench in 1999 fall between the two lines (DCB-49 and the limestone dissolution line) indicating that their waters are a sum of the influent water concentrations and the limestone dissolution (Figure 8). Unlike the 1999 trench samples, most of the current trench samples plot on the limestone dissolution line suggesting that the calcium and magnesium come from limestone dissolution with very little influence from DCB-49 water. These samples include those collected from DTT-1, DTT-1B, and the shallow sample from DTT-1A. As discussed above, the lower samples collected from DTT-1 and DTT-1B appear to be more representative of the upper trench chemistry than the bottom chemistry and so plot on the limestone dissolution line as well. The lower DTT-1A sample is the only trench sample that does not fall on the limestone dissolution line and shows a calcium to magnesium ratio more similar to DCB-49 (the influent water). Samples collected from DTT-1 after the 48-hour pump tests also fall between the limestone dissolution line and DCB-49 and most likely represent the lower more contaminated influent water being pulled in to the trench (Figure 9). Samples collected from DCB-50 presumably reflect the mixing of waters exiting the trench (having interacted with the limestone) and waters that have not been impacted by the trench. The DCB-50 calcium and magnesium concentrations and ratio from this study are consistent with the values from the 1999 study (Figure 10). 


\section{$\underline{\text { Aluminum Concentrations }}$}

As in 1999, aluminum concentrations in DCB-49 are linearly correlated with calcium concentrations (Figure 11). Although their concentrations are higher than they were in 1999, their ratio is consistent with the ratio found in the earlier study. This relationship between calcium and aluminum can also be used to calculate the original concentration of aluminum of the waters entering the trench. Using mass balance, the equations relating calcium to magnesium for the limestone and DCB-49 can be applied to determine the original calcium concentration of the influent waters (Figure 12) and thereby the correlative aluminum concentrations. Based on these calculations, the upper influent waters currently entering the trench have little aluminum. However, the bottom influent waters, as represented by the lower sample of DTT-1A and the samples collected after the pump tests, have aluminum concentrations between 65 and $75 \mathrm{mg} / \mathrm{L}$. DCB-49's field parameter profile and the 1999 DTT-1 depth discrete sampling (Washburn et al. 1999) also support this stratification of influent waters.

At the trench, white precipitates were observed during purging and were collected for $\mathrm{x}$ ray diffraction and $\mathrm{x}$-ray fluorescence analysis. These analyses indicate that an amorphous aluminum hydroxide is or has been precipitating in the trench (Appendix B6). It is likely that the precipitation of aluminum hydroxides is occurring in the portions of the trench where aluminum concentrations and $\mathrm{pH}$ are elevated. Figure 13 shows a solubility curve for a potential aluminum hydroxide precipitate. It suggests that aluminum and $\mathrm{pH}$ conditions are favorable for aluminum hydroxide precipitation in portions of the trench. The acidic conditions $(\mathrm{pH}<5)$ of the bottom of the trench (as indicated by the field profile) would not be as conducive for aluminum precipitation despite the high concentration of aluminum in the influent waters. Since the upper influent waters of the trench have low calculated aluminum concentrations, aluminum hydroxide precipitation may be most favored in the middle of the trench where there is a blending of water chemistries.

Comparison of 1999 and 2002 samples collected from DCB-50 indicates a decrease in aluminum concentrations in the downgradient waters, which most likely reflect the 
impact of the limestone trench (Table 4). The field parameter profile also implies that for this study waters within DCB-50's screened elevation are less stratified than they are upgradient of the trench and therefore the low aluminum concentration in the sample collected may reflect the water throughout this screened interval. It is likely that DCB-50 currently reflects a mixture of waters that have reacted with the trench (consequently having relatively high $\mathrm{pH}$ and low aluminum concentrations) and waters that have not come into contact with the limestone (having low $\mathrm{pH}$ and high aluminum concentrations).

\section{pH}

Results from this study indicate that the limestone trench remains effective at raising the $\mathrm{pH}$ and suggest that its impact may now be seen in the $\mathrm{pH}$ of DCB-50. Based on field parameter profiles and collected water samples, the upper portion of the trench (elevation 111-115.5 feet) appears to be able to raise the $\mathrm{pH}$ of influent waters to 5 or greater (Figure 7). The upper 3 feet of this portion consists of waters that primarily reflect limestone dissolution as evidenced by the $\mathrm{pH}$ 's of 7 and calcium to magnesium ratios of collected water samples. In contrast, the lower part of the trench (elevation 108.5-110.5) consists of more acidic waters with pH's near 4. In the downgradient well, DCB-50, $\mathrm{pH}$ remains constant near or above 5 throughout the screen zone. Additionally, samples collected after purging and the 48-hour pumps tests also had $\mathrm{pH}$ 's above 5, which may reflect the extensive nature of these waters. These $\mathrm{pH}$ 's are higher than those seen in DCB-50 in the 1999 study and are supporting evidence that the limestone trench is impacting downgradient waters (Table 4).

\section{Geochemical Conclusions}

The following are the primary geochemical conclusions associated with this evaluation:

- The geochemistries of upgradient plume waters and waters within the limestone trench are highly stratified as documented in the 1999 study.

- Overall, the limestone trench remains an effective treatment for increasing the $\mathrm{pH}$ and removing aluminum near the DCPRB. Analysis of collected precipitates indicates that aluminum removal is occurring through the precipitation of aluminum hydroxide 
minerals. Iron armoring of the limestone (i.e. the precipitation of ferric hydroxide coatings) does not appear to be significant for the following reasons:

1) Waters within the upper part of the trench have low iron concentrations and have $\mathrm{pH}$ 's and calcium to magnesium ratios indicating that the limestone is still active, and

2) Waters within the lower part of the trench are dominated by ferrous iron as indicated by iron speciation analyses (see Appendix B-4).

- The impact of the limestone trench on downgradient waters is evident in the increase of $\mathrm{pH}$ and decrease of aluminum in DCB-50. In addition, a profile of field parameters within DCB-50's screen zone suggests that waters downgradient of the trench may be less stratified.

- The longevity and effectiveness of the limestone trench may be impacted by the buildup of aluminum hydroxide precipitates. It is unclear whether aluminum hydroxide precipitation is contributing to the difference in reactivity of the limestone in the upper (more reactive) part versus the lower (less reactive) part of the trench. The stratification of the influent waters, differences in residence times, the buildup of aluminum hydroxide precipitates, or a combination of these factors may be contributing to the differences of limestone reactivity in the trench. Methods that could be used to determine the effects of aluminum hydroxide precipitation on limestone reactivity in the trench include:

1) Field measurement profiles before and after heavy purging to elucidate whether the removal of aluminum precipitates increases the limestone reactivity, and

2) Introducing retrievable pieces of limestone at various depths within the trench and evaluating the impacts from the stratified influent waters (e.g. dissolution, precipitation of aluminum hydroxides) on the limestone pieces. 


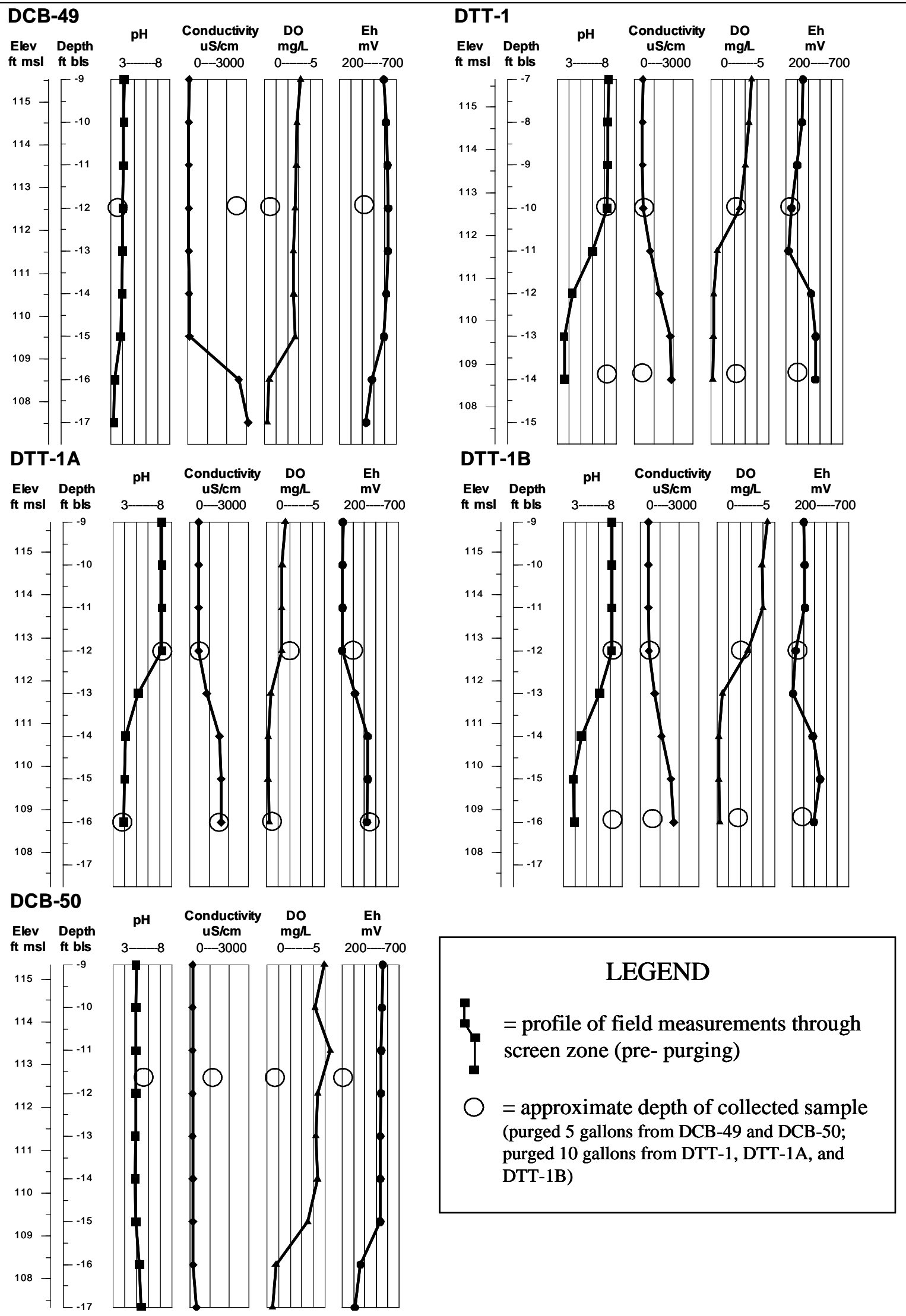

Figure 7. Field Measurement Profiles and Collected Samples 


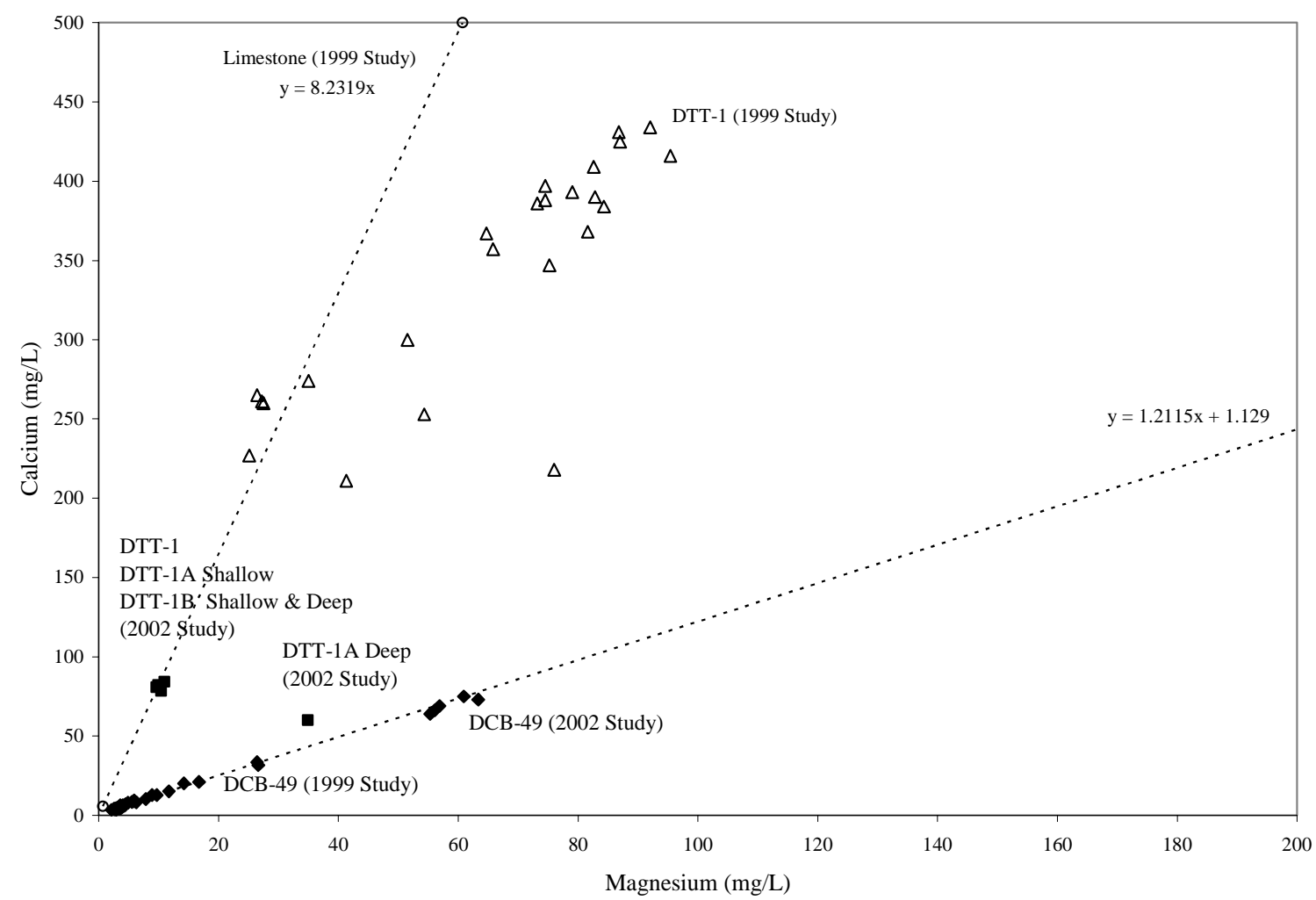

Figure 8. DCB-49 and DTT-1 Calcium Versus Magnesium Concentrations

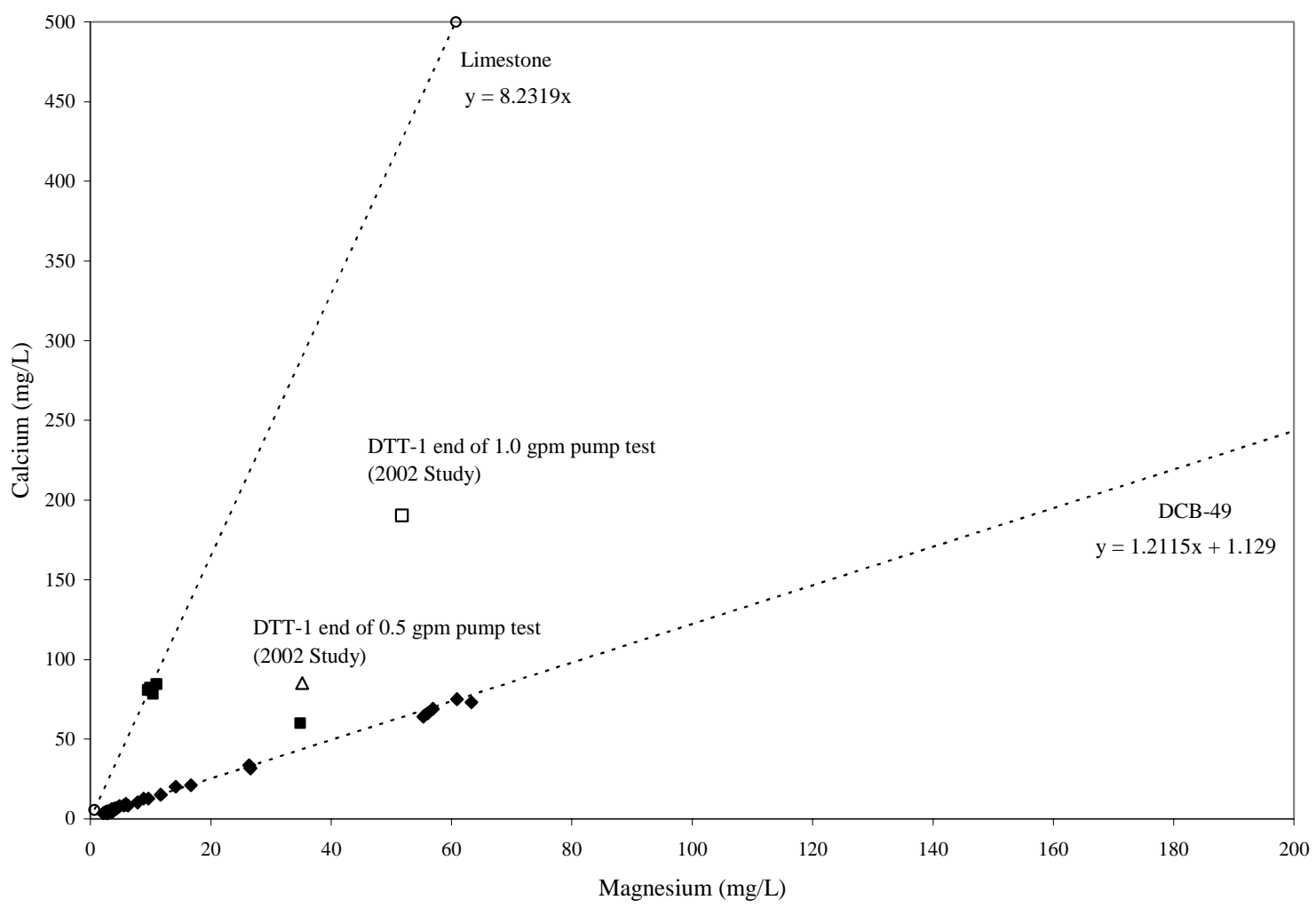

Figure 9. DTT-1 Post Pump Tests Calcium Versus Magnesium Concentrations 


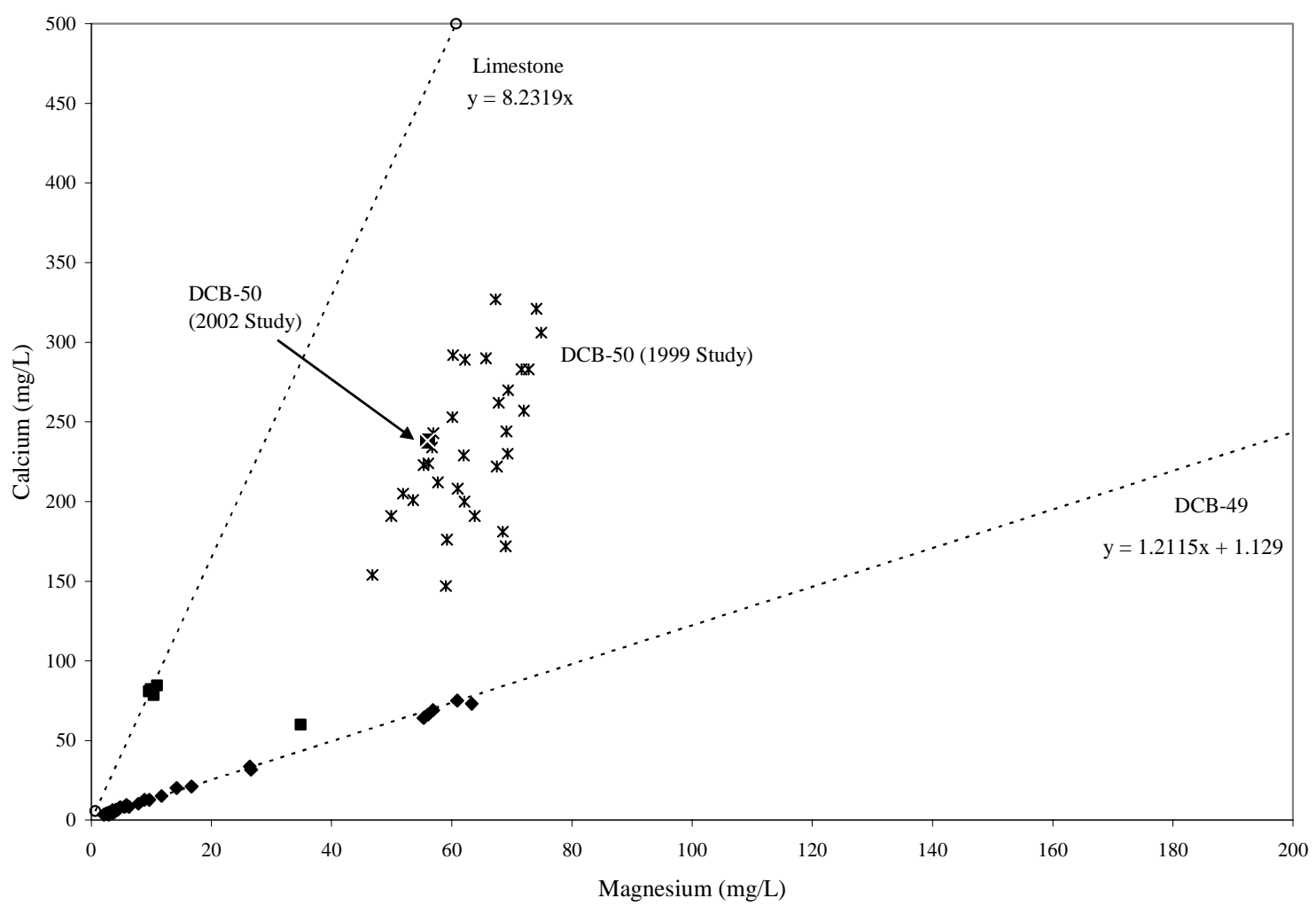

Figure 10. DCB-50 Calcium Versus Magnesium Concentrations

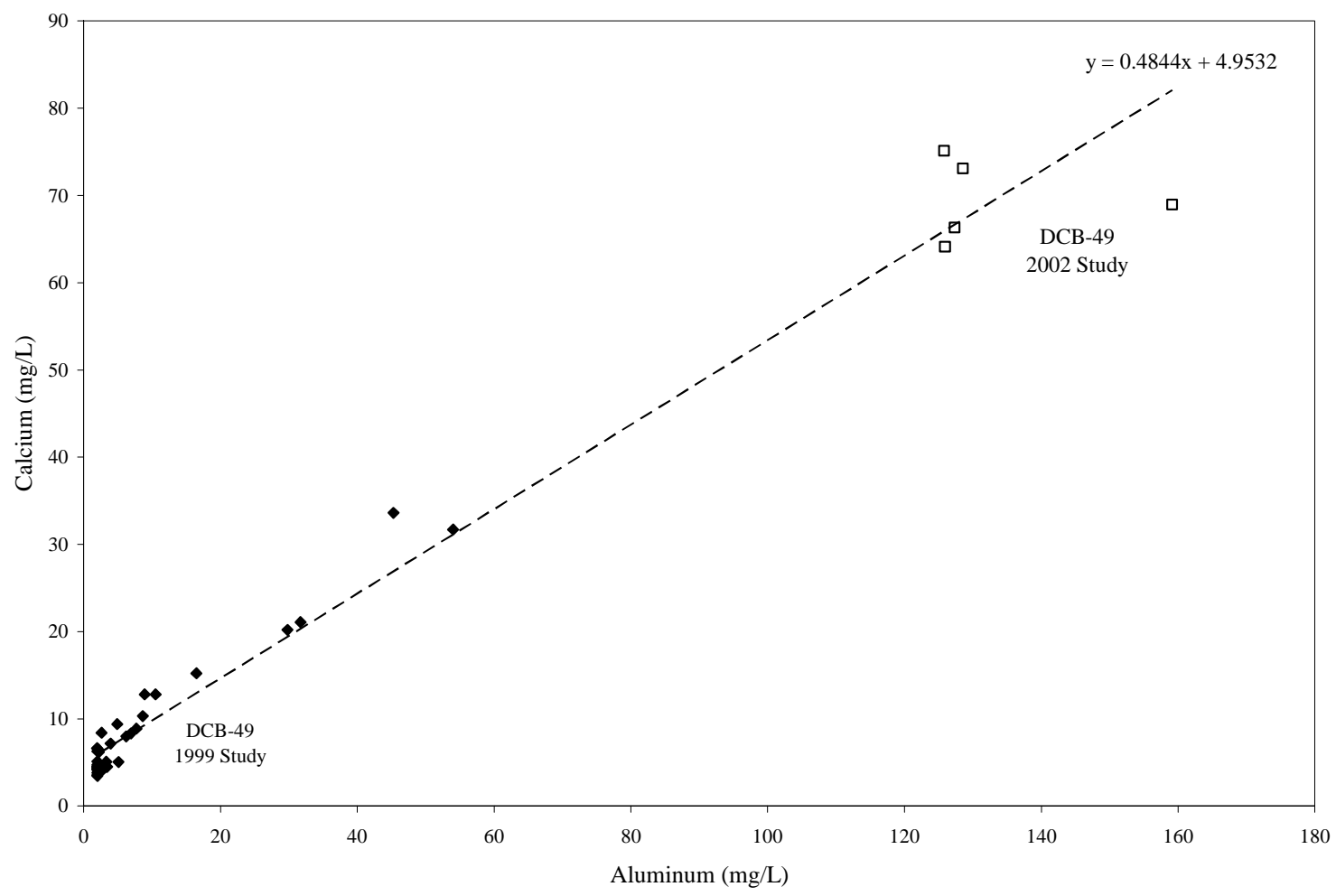

Figure 11. DCB-49 Calcium Versus Aluminum Concentrations 


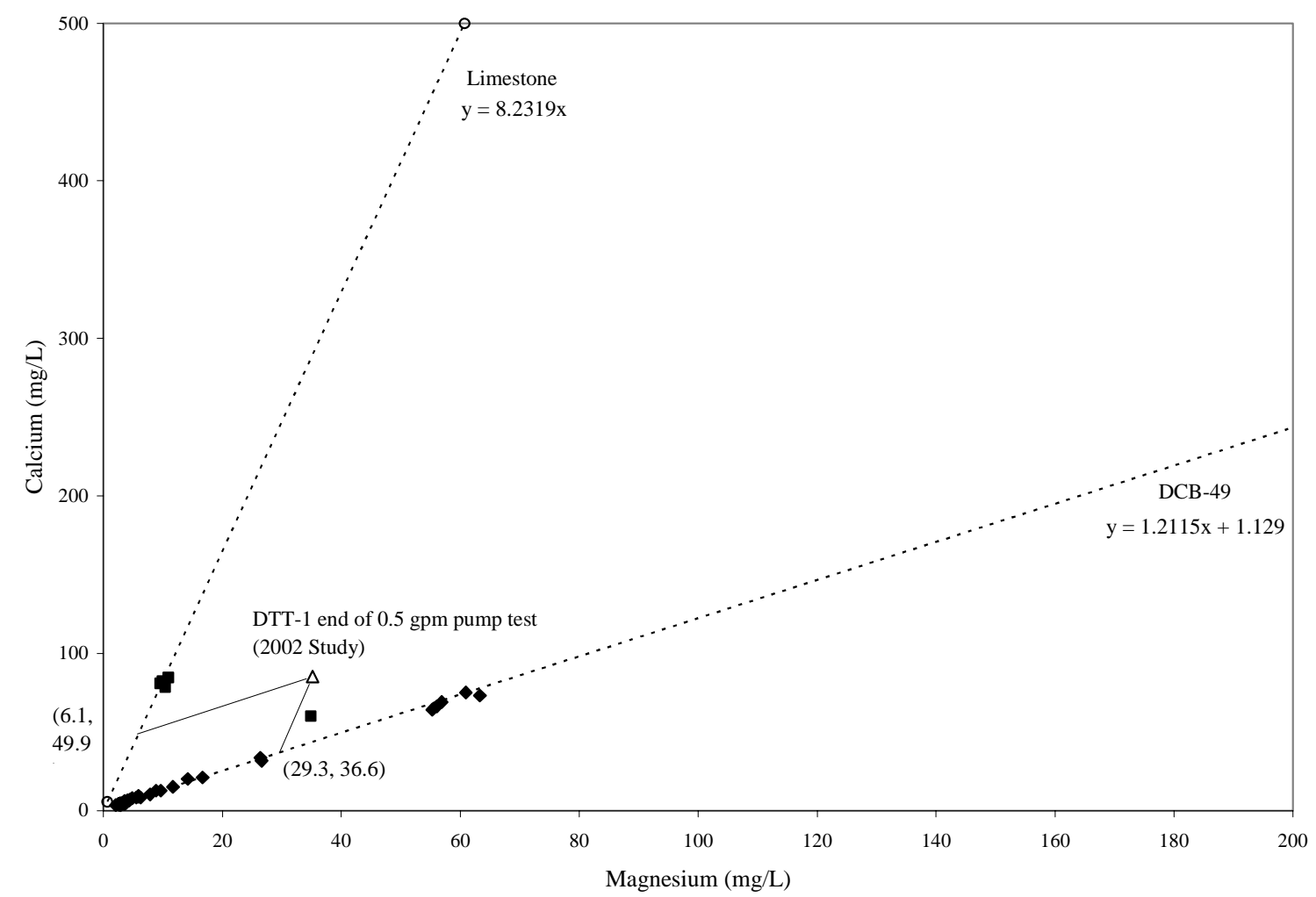

Figure 12. Method of Calculation of Calcium and Magnesium Concentrations in Influent Water

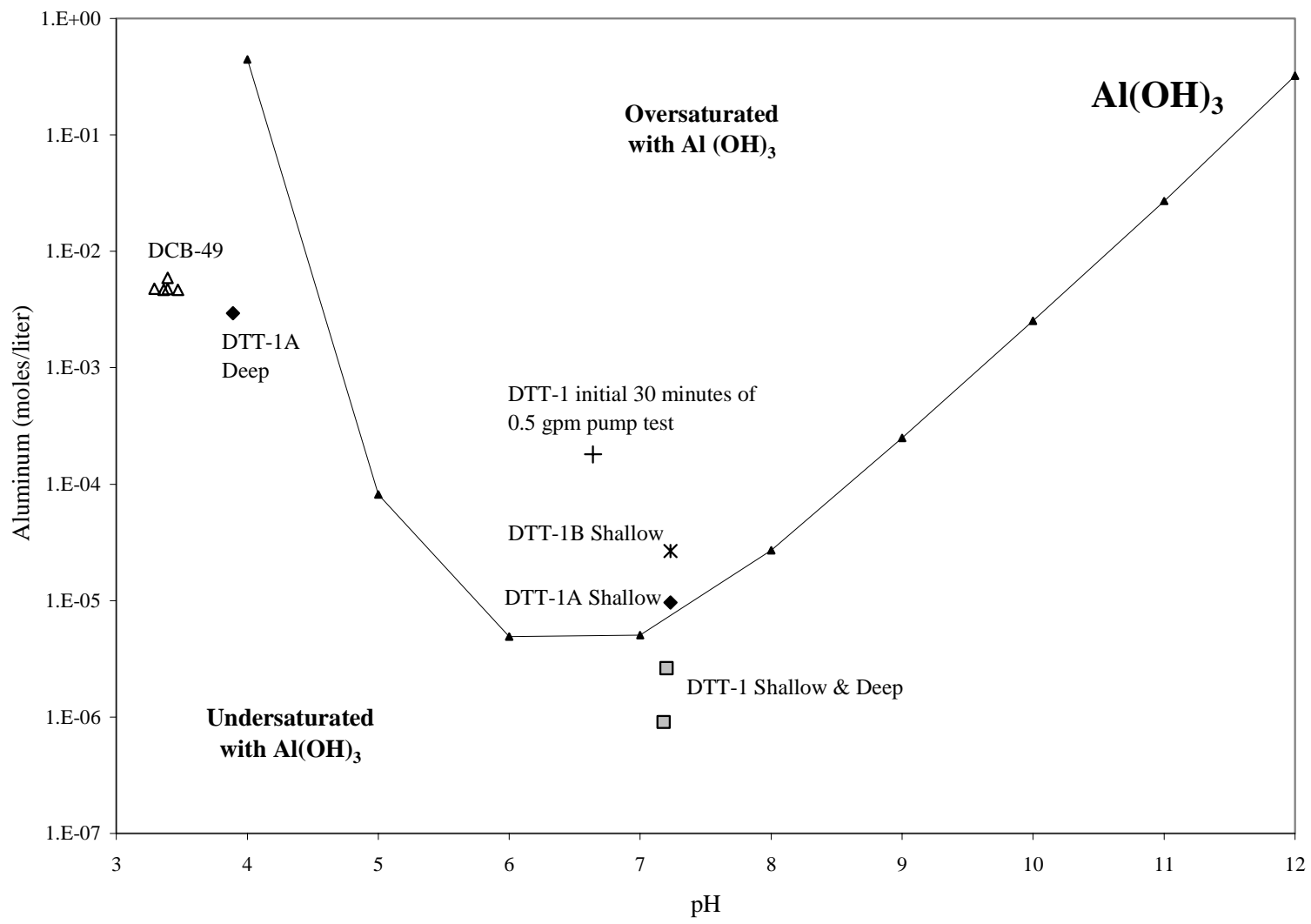

Figure 13. $\quad \mathrm{Al}(\mathrm{OH})_{3}$ Solubility Diagram 
Table 4. DCB-50 Aluminum and pH Concentrations

\begin{tabular}{|c|c|c|c|}
\hline Parameter & Statistical Parameter & 1999 Value & \multirow{2}{*}{ 2002 Value $^{1}$} \\
\hline \multirow{3}{*}{ Aluminum (mg/L) } & Minimum & 28.8 & \multirow{2}{*}{0.648} \\
\cline { 2 - 4 } & Maximum & 100 & \\
\cline { 2 - 4 } & Median & 51.35 & 1 \\
\cline { 2 - 4 } & \# of samples & 32 & 5.68 \\
\hline \multirow{4}{*}{$\mathrm{pH}$} & Minimum & 3.38 & 6.04 \\
\cline { 2 - 4 } & Maximum & 5.04 & 5.89 \\
\cline { 2 - 4 } & Median & 3.88 & 3 \\
\cline { 2 - 4 } & \# of samples & 32 & \\
\hline
\end{tabular}

${ }^{1}$ One sample collected for $\mathrm{Al}$ analysis on 12/6/02; $\mathrm{pH}$ data from 12/6/02 during and after sample collection and 12/18/02 at the end of the 48-hour 1 gpm pump test

\subsection{DTT-1 SULFATE REDUCTION POTENTIAL EVALUATION}

To address the existing sulfate reduction potential that exists within the trench the following evaluations have been performed:

- The existing limestone trench SRB and general microbial activity have been evaluated, and

- Existing limestone trench conditions have been compared to both optimal sulfate reduction conditions and the current sulfate reduction, field study (i.e. pre and post soybean oil injection conditions at the D-Area Interceptor Well (DIW-1)).

\section{$\underline{\text { Sulfate Reducing Bacteria (SRB) }}$}

Microorganisms that couple the oxidation of carbon substrates to the reduction of sulfate for energy production and growth are known as sulfate reducing bacteria (SRB). In this process sulfate serves the same function as oxygen does for aerobic respiration (i.e. terminal electron acceptor). However SRB cannot use oxygen as terminal electron acceptors. In fact oxygen is toxic to SRB above trace levels.

During growth of SRB carbon is oxidized and sulfate is reduced to hydrogen sulfide $\left(\mathrm{H}_{2} \mathrm{~S}\right)$. Hydrogen sulfide can also react with metals in the environment and result in their immobilization via the formation of reduced minerals. When SRB oxidize a carbon source the resulting bicarbonate $\left(\mathrm{HCO}_{3}{ }^{-}\right)$serves to buffer the system (i.e. $\mathrm{HCO}_{3}{ }^{-}$can combine with additional hydrogen ions to form $\mathrm{H}_{2} \mathrm{CO}_{3}$ ). This in turn can react with 
metals to form carbonate minerals. The reduction of sulfate consumes electrons and results in an increased $\mathrm{pH}$ of the system. The increased $\mathrm{pH}$ can also result in metal immobilization through metal hydroxide formation. The ubiquity of SRB in the environment and their ability to catalyze biogeochemical transformation of minerals has been exploited for use in bioremediation.

\section{Optimal Sulfate Reduction Conditions}

$\mathrm{SRB}$ are widespread in the environment and grow best in a $\mathrm{pH}$ range from 5.5 - 9.0. However sulfate reduction has been recorded from acid mine drainage and a fresh water peat bog with $\mathrm{pH}$ values as low as 2.5. This may be due to the formation of biofilms of SRB around geologic substrates that provide a more alkaline microenvironment and therefore allow sulfate reduction to occur under otherwise harsh conditions.

Lactate and pyruvate are almost universally used as an organic carbon substrate and electron donor by SRB. Lactate is ideal for increasing SRB activity, however concentrations above $6 \mathrm{~g} / \mathrm{L}$ may be inhibitory to SRB (Turick et al. 2002). Vegetable oil has been used in the bioremediation industry as a slow release carbon source for primarily chlorinated organic degradation and based on results to date is viewed favorably. Vegetable oil can provide a significant amount of carbon to SRB as a result of its breakdown by fermentative bacteria.

SRB compete for organic carbon substrates and micronutrients (nitrogen and phosphate) with both aerobic bacteria (i.e. use $\mathrm{O}_{2}$ as the terminal electron acceptor) and other anaerobic bacteria that can utilize terminal electron acceptors other than sulfate. The major anaerobic competitors use the following as terminal electron acceptors: $\mathrm{NO}_{3}{ }^{-}$ (nitrate reducers), $\mathrm{Mn}^{+4}$ (manganese reducers), $\mathrm{Fe}^{+3}$ (iron reducers) and $\mathrm{CO}_{2}$ (methanogens). When sulfate concentrations are high relative to $\mathrm{O}_{2}, \mathrm{NO}_{3}{ }^{-}, \mathrm{Mn}^{+4}$, and $\mathrm{Fe}^{+3}, \mathrm{SRB}$ are expected to predominate. Sulfate reduction is more thermodynamically favorable than methanogenesis and will therefore predominate so long as significant sulfate is available regardless of the $\mathrm{CO}_{2}$ concentrations. 


\section{Existing Microbial Activity within and Downgradient of the Limestone Trench}

Existing microbial activity including SRB within and downgradient of the limestone trench can be evaluated by comparing the upgradient values of total organic carbon (TOC), total microbes, sulfate/hydrogen sulfide, SRBs, $\mathrm{pH}$, Eh (redox potential), and dissolved oxygen (DO) to that within and downgradient of the trench. Table 5 provides these parameters for monitoring well DCB-49 (upgradient), the trench itself (DTT-1A, DTT-1, and DTT-1B), and monitoring well DCB-50 (downgradient). However the following parameters can not be used as evidence of increased microbial activity within and downgradient of the trench for the following reasons:

- TOC can not be used, due to the very low TOC levels, and

- $\mathrm{pH}$ can not be used, due to the presence of the limestone, which increases the $\mathrm{pH}$ abiotically.

The following parameters (Table 5) are indicative of microbial growth as discussed:

- The total number of microbes is greater by about one order of magnitude within (DTT-1A, DTT-1, and DTT-1B) and downgradient (DCB-50) of the limestone trench from that upgradient (DCB-49) indicating that the limestone trench has been conducive to overall microbial growth. Since SRB often grow as part of complex microbial consortia, increased overall bacterial populations would be conducive to SRB activity, especially in environments that are not optimum to SRB. Additionally the total microbial count was even higher within sludge recovered from the trench (see Appendix C-1).

- The sulfate/hydrogen sulfide data, in particular, is indicative of SRB growth, since SRB decrease sulfate and increase hydrogen sulfide concentrations as a function of growth. As shown in Table 5 sulfate has decreased and hydrogen sulfide has increased within and downgradient of the limestone trench from that upgradient indicating that the limestone trench has been conducive to SRB growth. Hydrogen sulfide levels are temporal since it readily combines with many metals to form metal sulfide precipitates and it is transported as gas bubbles out of the groundwater. Therefore a direct one to one correlation between the reduction in sulfate levels and 
increases in hydrogen sulfide levels is not possible. Additionally it is unlikely that the low sulfate levels generally found in the trench are entirely due to SRB growth. Plume stratification could also impact the level of sulfate within the trench.

- More directly the SRB concentration has slightly increased within and downgradient of the limestone trench from that upgradient again indicating that the limestone trench has been conducive to SRB growth. Additionally the SRB concentration was even higher within sludge recovered from the trench (see Appendix C-1).

- The Eh has decreased within and downgradient of the limestone trench from that upgradient which is indicative of anaerobic activity.

The dissolved oxygen levels within the limestone trench are higher than either the upgradient or downgradient levels. This may be due to the proximity of the limestone to the ground surface and the large void spaces of the limestone, which facilitates the transfer of atmospheric air (i.e. oxygen) into the trench water. However as shown in Figure 7 dissolved oxygen concentrations decrease as a function of depth in all the wells tested which is indicative of aerobic microbial activity.

Overall the data indicates that the limestone trench has resulted in increased microbial activity including SRB activity.

\section{Limestone Trench Comparison to Optimal Sulfate Reduction Conditions and the}

\section{Current Sulfate Reduction Field Study}

Optimal sulfate reduction conditions are provided in Table 6 for comparison to the conditions upgradient (DCB-49), within (DTT-1A, DTT-1, and DTT-1B), and downgradient (DCB-50) of the limestone trench. The optimal conditions in this table are somewhat conservative because SRB activity can occur in microbial biofilms where conditions approach optimum for SRB even though the environment outside the biofilm is less than optimal. The ability to isolate SRB from environments as harsh as DCB-49 indicates that bacterial biofilms are present. As shown in the table the presence of the limestone trench has had the following beneficial impacts relative to approaching optimal sulfate reduction conditions from upgradient conditions (DCB-49): 
- The $\mathrm{pH}$ has increased to within the optimal range within and downgradient of the trench.

- The Eh has decreased toward optimal conditions.

- The total SRB numbers have increased.

- The manganese, iron, and aluminum concentrations have all decreased.

While conditions have improved with flow through the limestone not all parameters are within the optimal range. However as shown in Table 7 the conditions downgradient (DCB-50) of the limestone trench are generally better than the pre-injection conditions at the D-Area Interceptor Well (DIW-1) as represented by data from piezometer DIWP07A, where soybean oil was injected as an organic carbon substrate. The primary limiting factor to the promotion of sulfate reduction remediation at the limestone trench is the lack of available organic carbon substrate, since the rate of SRB growth is largely dependent on the type and amount of organic carbon entering the system. Due to the low organic carbon concentrations at the trench, SRB growth was expected to be slow as indicated by the data. Accelerated SRB growth and subsequent metals remediation could be accomplished through the addition of a suitable organic carbon substrate such as soybean oil similar to what has been accomplished at DIW-1. However injection of soybean oil within the limestone trench is not recommended for the following reasons:

- As seen in Table 5 the sulfate concentrations within the limestone trench are considerably less than downgradient of the trench. As outlined previously higher sulfate concentrations favor SRB dominance, since sulfate is the terminal electron acceptor.

- Also as seen in Table 5 the dissolved oxygen concentration with the limestone trench is higher than downgradient of the trench. As outlined previously oxygen is toxic to SRB and the downgradient concentrations are more favorable.

- Injection of soybean oil within the limestone will result in coating the limestone and may reduce its geochemical activity. Additionally sulfate reduction promoted within the limestone will result in the precipitation of metals on the limestone, which may also reduce its geochemical activity. 
For these reasons it is recommended that if soybean oil is injected in conjunction with the limestone trench that it be injected downgradient of the trench.

\section{DTT-1 Sulfate Reduction Potential Conclusions}

Microbial activity, including SRBs, is greater within and downgradient of the trench than upgradient, primarily due to the increased $\mathrm{pH}$ produced by the limestone trench. Additionally the limestone trench has in general improved conditions both within and downgradient of the trench relative to optimal sulfate reduction conditions from that upgradient. In fact the conditions within and downgradient of the trench are markedly better relative to optimal sulfate reduction conditions than that of DIW-1 prior to injection of the soybean oil into it. The injection of soybean oil into DIW-1 has successfully promoted sulfate reduction remediation in that location. The primary limiting factor to the promotion of sulfate reduction remediation at the limestone trench is the lack of available organic carbon substrate therefore the addition of soybean oil should result in such remediation. However due primarily to the possibility of limestone deactivation with the injection of soybean oil into the limestone trench, it is recommended that if soybean oil at this location that it be done downgradient of the trench.

Table 5. Microbial Parameters

\begin{tabular}{|l|l|l|l|l|l|l|l|l|c|}
\hline $\begin{array}{c}\text { Sample } \\
\text { Location }\end{array}$ & $\begin{array}{c}\text { Sample } \\
\text { Depth } \\
(\mathrm{ft})\end{array}$ & $\begin{array}{c}\text { TOC } \\
(\mathrm{mg} / \mathrm{L})\end{array}$ & $\begin{array}{c}\text { Total } \\
\text { Microbes } \\
(\text { cells/ml })\end{array}$ & $\begin{array}{c}\mathrm{SO}_{4} \\
(\mathrm{mg} / \mathrm{L})\end{array}$ & $\begin{array}{c}\mathrm{H}_{2} \mathrm{~S} \\
(\mathrm{mg} / \mathrm{L})\end{array}$ & $\begin{array}{c}\text { SRB } \\
(\text { cells/ml })\end{array}$ & \multicolumn{1}{c|}{$\mathrm{pH}$} & $\begin{array}{c}\text { Eh } \\
(\mathrm{mV})\end{array}$ & $\begin{array}{c}\text { DO } \\
(\mathrm{mg} / \mathrm{L})\end{array}$ \\
\hline DCB-49 & 11.7 & 3.1 & $3.95 \mathrm{E}+04$ & 2556 & $<0.05$ & $1.84 \mathrm{E}+01$ & 3.29 & 432 & 0.541 \\
\hline DTT-1A & 11.9 & 8.3 & $3.29 \mathrm{E}+05$ & 67.91 & 0.1 & $4.60 \mathrm{E}+01$ & 7.23 & 304 & 2.012 \\
\hline DTT-1A & 15.9 & 2.3 & $4.00 \mathrm{E}+05$ & 1465 & 0.05 & $3.00 \mathrm{E}+01$ & 3.89 & 449 & 0.490 \\
\hline DTT-1 & 9.8 & 9.4 & $2.72 \mathrm{E}+05$ & 72.54 & 0.1 & $8.60 \mathrm{E}+01$ & 7.18 & 255 & 2.114 \\
\hline DTT-1 & 13.8 & 8.5 & $3.29 \mathrm{E}+05$ & 67.89 & 0.05 & $8.60 \mathrm{E}+01$ & 7.2 & 292 & 2.277 \\
\hline DTT-1B & 11.9 & 10.2 & $1.79 \mathrm{E}+05$ & 78.62 & 0.08 & $4.60 \mathrm{E}+01$ & 7.23 & 267 & 1.920 \\
\hline DTT-1B & 15.9 & 7.4 & $1.14 \mathrm{E}+05$ & 75.76 & 0.08 & $8.60 \mathrm{E}+01$ & 7.28 & 284 & 1.822 \\
\hline DCB-50 & 11.5 & 7.6 & $2.37 \mathrm{E}+05$ & 1262 & 0.14 & $8.60 \mathrm{E}+01$ & 5.89 & 224 & 0.654 \\
\hline
\end{tabular}

Note to Table 5:

$\mathrm{TOC}=$ total organic carbon; $\mathrm{SRB}=$ sulfate reducing bacteria; $\mathrm{DO}=$ dissolved oxygen See Appendix C-1 for additional details concerning this data 
Table 6. Limestone Trench Conditions Versus Optimal Sulfate Reduction Conditions

\begin{tabular}{|c|c|c|c|c|}
\hline Parameter & Optimal Condition $^{1}$ & DCB-49 & $\begin{array}{l}\text { DTT-1A, DTT-1, } \\
\text { and DTT-1B }\end{array}$ & DCB-50 \\
\hline$\overline{\mathrm{pH}}$ & 5.5 to 9 & 3.29 & $\begin{array}{l}3.89-7.28 \\
(6.67 \text { average })\end{array}$ & 5.89 \\
\hline Eh & 0 to $-150 \mathrm{mV}$ & 432 & $\begin{array}{l}255-449 \\
(308 \text { average })\end{array}$ & 224 \\
\hline Total SRBs & $\begin{array}{l}1.0 \mathrm{E}+5-1.0 \mathrm{E}+7 \\
\text { cells/ml }\end{array}$ & $1.84 \mathrm{E}+01$ cells $/ \mathrm{ml}$ & $\begin{array}{l}3.0 \mathrm{E}+01-8.6 \mathrm{E}+01 \\
\text { cells/ml } \\
(6.3 \mathrm{E}+01 \text { average })\end{array}$ & $8.6 \mathrm{E}+01$ cells $/ \mathrm{ml}$ \\
\hline \begin{tabular}{|l} 
Organic \\
Carbon \\
Substrate
\end{tabular} & $\begin{array}{l}1000-3000 \mathrm{mg} / \mathrm{L} \text { as } \\
\text { Lactate } \\
(>6000 \mathrm{mg} / \mathrm{L} \text { Lactate } \\
\text { could be inhibitory })^{2}\end{array}$ & $\mathrm{TOC}=3.1 \mathrm{mg} / \mathrm{L}$ & $\begin{array}{l}\text { TOC }=2.3-10.2 \\
(7.68 \text { average })\end{array}$ & TOC $=7.6 \mathrm{mg} / \mathrm{L}$ \\
\hline $\begin{array}{l}\text { Nitrogen: } \\
\mathrm{NO}_{3}^{-}\end{array}$ & $\begin{array}{l}\mathrm{mg} / \mathrm{L} \text { range of soluble } \\
\text { organic or inorganic }\end{array}$ & $<0.5 \mathrm{mg} / \mathrm{L}$ & $\begin{array}{l}<0.5-3.82 \mathrm{mg} / \mathrm{L}(2.68 \\
\text { average })\end{array}$ & $<0.5 \mathrm{mg} / \mathrm{L}$ \\
\hline $\mathrm{NO}_{2}^{-}$ & nitrogen & $10.13 \mathrm{mg} / \mathrm{L}$ & $\begin{array}{l}<0.5-6 \mathrm{mg} / \mathrm{L} \\
(1.58 \text { average })\end{array}$ & $<0.5 \mathrm{mg} / \mathrm{L}$ \\
\hline $\mathrm{NH}_{4}^{+}$ & & $<0.5 \mathrm{mg} / \mathrm{L}$ & $<0.5 \mathrm{mg} / \mathrm{L}$ & $<0.5 \mathrm{mg} / \mathrm{L}$ \\
\hline $\begin{array}{l}\text { Phosphate } \\
\left(\mathrm{PO}_{4}^{-3}\right)\end{array}$ & $\begin{array}{l}\mathrm{mg} / \mathrm{L} \text { range of soluble } \\
\text { organic or inorganic } \\
\text { phosphate }\end{array}$ & $<0.5 \mathrm{mg} / \mathrm{L}$ & $<0.5 \mathrm{mg} / \mathrm{L}$ & $<0.5 \mathrm{mg} / \mathrm{L}$ \\
\hline \begin{tabular}{|l} 
Dissolved \\
Oxygen $\left(\mathrm{O}_{2}\right)$
\end{tabular} & $\begin{array}{l}<1 \mathrm{mg} / \mathrm{L} \\
\text { (toxic to SRB) }\end{array}$ & $0.542 \mathrm{mg} / \mathrm{L}$ & $\begin{array}{l}0.49-2.28 \mathrm{mg} / \mathrm{L} \\
(1.77 \text { average })\end{array}$ & $0.654 \mathrm{mg} / \mathrm{L}$ \\
\hline $\begin{array}{l}\text { Nitrate } \\
\left(\mathrm{NO}_{3}^{-}\right)\end{array}$ & $\begin{array}{l}\text { Small fraction of } \mathrm{SO}_{4} \\
\text { concentration }\end{array}$ & $<0.5 \mathrm{mg} / \mathrm{L}$ & $\begin{array}{l}<0.5-3.82 \mathrm{mg} / \mathrm{L}(2.68 \\
\text { average })\end{array}$ & $<0.5 \mathrm{mg} / \mathrm{L}$ \\
\hline $\begin{array}{l}\text { Manganese } \\
\left(\mathrm{Mn}^{+4}\right)^{3}\end{array}$ & $\begin{array}{l}\text { Small fraction of } \mathrm{SO}_{4} \\
\text { concentration }\end{array}$ & $\mathrm{Mn}_{\text {total }}=4.8 \mathrm{mg} / \mathrm{L}$ & $\begin{array}{l}\mathrm{Mn}_{\text {total }}<0.001-3.277 \\
\mathrm{mg} / \mathrm{L} \\
(0.546 \text { average })\end{array}$ & $\mathrm{Mn}_{\text {total }}=2.418 \mathrm{mg} / \mathrm{L}$ \\
\hline $\begin{array}{l}\text { Ferric Iron } \\
\left(\mathrm{Fe}^{+3}\right)\end{array}$ & $\begin{array}{l}\text { Small fraction of } \mathrm{SO}_{4} \\
\text { concentration }\end{array}$ & $\begin{array}{l}\mathrm{Fe}_{\text {total }}=672.87 \\
\text { All Fe }\end{array}$ & $\begin{array}{l}\mathrm{Fe}_{\text {total }}<0.004-374.3 \\
\mathrm{mg} / \mathrm{L} \\
(62.4 \text { average }) \\
\mathrm{All} \mathrm{Fe}^{+2}\end{array}$ & $\begin{array}{l}\mathrm{Fe}_{\text {total }}=252.05 \mathrm{mg} / \mathrm{L} \\
\text { All Fe }^{+2}\end{array}$ \\
\hline $\begin{array}{l}\text { Sulfate } \\
\left(\mathrm{SO}_{4}^{-2}\right)\end{array}$ & $\begin{array}{l}\text { Significant } \mathrm{SO}_{4} \\
\text { concentrations; } \\
<170 \mathrm{mg} / \mathrm{L} \mathrm{H}_{2} \mathrm{~S} \text { (higher } \\
\text { concentrations may } \\
\text { inhibit SRB) }\end{array}$ & $\begin{array}{l}\mathrm{SO}_{4}^{-2}=2556 \mathrm{mg} / \mathrm{L} \\
\mathrm{H}_{2} \mathrm{~S}<0.05 \mathrm{mg} / \mathrm{L}\end{array}$ & $\begin{array}{l}\mathrm{SO}_{4}^{-2}=67.89-1465 \\
\mathrm{mg} / \mathrm{L} \\
(305 \text { average }) \\
\mathrm{H}_{2} \mathrm{~S}=0.05-0.1 \mathrm{mg} / \mathrm{L} \\
(0.08 \text { average })\end{array}$ & $\begin{array}{l}\mathrm{SO}_{4}^{-2}=1262 \mathrm{mg} / \mathrm{L} \\
\mathrm{H}_{2} \mathrm{~S}=0.14 \mathrm{mg} / \mathrm{L}\end{array}$ \\
\hline $\begin{array}{l}\text { Acetate } \\
\mathrm{CO}_{2} \\
\mathrm{H}_{2}\end{array}$ & $\begin{array}{l}\text { Eh > }>-150 \mathrm{mV} \\
\text { presence of significant } \\
\text { sulfate }\end{array}$ & $\begin{array}{l}\mathrm{Eh}=432 \mathrm{mV} \\
\mathrm{SO}_{4}^{-2}=2556 \mathrm{mg} / \mathrm{L}\end{array}$ & $\begin{array}{l}\mathrm{Eh}=255-449 \mathrm{mV} \\
(308 \text { average }) \\
\mathrm{SO}_{4}^{-2}=67.89-1465 \\
\mathrm{mg} / \mathrm{L} \\
(305 \text { average })\end{array}$ & $\begin{array}{l}\mathrm{Eh}=224 \mathrm{mV} \\
\mathrm{SO}_{4}{ }^{-2}=1262 \mathrm{mg} / \mathrm{L}\end{array}$ \\
\hline Aluminum & $\begin{array}{l}\text { Low concentrations } \\
\text { (toxic to SRB) }\end{array}$ & $128.55 \mathrm{mg} / \mathrm{L}$ & $\begin{array}{l}0.024-79.31 \mathrm{mg} / \mathrm{L} \\
(13.4 \mathrm{mg} / \mathrm{L})\end{array}$ & $0.648 \mathrm{mg} / \mathrm{L}$ \\
\hline
\end{tabular}

Sources for optimal sulfate reduction conditions: Benner et al. 1999; Chapelle 1993; EPA 1999; Fauque 1995; Fenchel et al. 1998; Thomas et al. 1999

${ }^{2}$ Turick et al. 2002

${ }^{3}$ Dissolved Mn data may include both ${ }^{+2}$ and ${ }^{+4}$ species; at the $\mathrm{pH}$ and Eh ranges given above, $\mathrm{Mn}^{+2}$ should be the dominant species present. 
Table 7. D-Area Interceptor Well (DIW-1) Versus Limestone Trench Conditions

\begin{tabular}{|c|c|c|c|c|}
\hline Parameter & Optimal Condition $^{1}$ & DCB-50 & $\begin{array}{l}\text { DIW-P07A }^{5} \\
\text { (Pre-Injection) }^{\text {Pro }}\end{array}$ & $\begin{array}{c}\text { DIW-P07A }^{5} \\
\text { (Post-Injection) }\end{array}$ \\
\hline $\mathrm{pH}$ & 5.5 to 9 & 5.89 & 3.11 & 5.51 \\
\hline Eh & 0 to $-150 \mathrm{mV}$ & $224 \mathrm{mV}$ & $581 \mathrm{mV}$ & $129 \mathrm{mV}$ \\
\hline Total SRBs & $\begin{array}{l}1.0 \mathrm{E}+5-1.0 \mathrm{E}+7 \\
\text { cells } / \mathrm{ml}\end{array}$ & $8.6 \mathrm{E}+01 \mathrm{cells} / \mathrm{ml}$ & $<7.20 \mathrm{E}+00$ cells $/ \mathrm{ml}$ & $>2.20 \mathrm{E}+07$ cells $/ \mathrm{ml}^{4}$ \\
\hline \begin{tabular}{|l|} 
Organic \\
Carbon \\
Substrate
\end{tabular} & $\begin{array}{l}1000-3000 \mathrm{mg} / \mathrm{L} \text { as } \\
\text { Lactate } \\
(>6000 \mathrm{mg} / \mathrm{L} \text { Lactate } \\
\text { could be inhibitory })^{2}\end{array}$ & $\mathrm{TOC}=7.6 \mathrm{mg} / \mathrm{L}$ & $\mathrm{TOC}=8.22 \mathrm{mg} / \mathrm{L}$ & $\mathrm{TOC}=542 \mathrm{mg} / \mathrm{L}$ \\
\hline \multirow{3}{*}{$\begin{array}{l}\text { Nitrogen: } \\
\mathrm{NO}_{3}^{-} \\
\mathrm{NO}_{2}^{-} \\
\mathrm{NH}_{4}^{+}\end{array}$} & \multirow{3}{*}{$\begin{array}{l}\mathrm{mg} / \mathrm{L} \text { range of soluble } \\
\text { organic or inorganic } \\
\text { nitrogen }\end{array}$} & $<0.5 \mathrm{mg} / \mathrm{L}$ & $<0.5 \mathrm{mg} / \mathrm{L}$ & $<0.5 \mathrm{mg} / \mathrm{L}$ \\
\hline & & $<0.5 \mathrm{mg} / \mathrm{L}$ & $1.8 \mathrm{mg} / \mathrm{L}$ & $<0.5 \mathrm{mg} / \mathrm{L}$ \\
\hline & & $<0.5 \mathrm{mg} / \mathrm{L}$ & $1.5 \mathrm{mg} / \mathrm{L}$ & $<0.5 \mathrm{mg} / \mathrm{L}$ \\
\hline $\begin{array}{l}\text { Phosphate } \\
\left(\mathrm{PO}_{4}^{-3}\right)\end{array}$ & $\begin{array}{l}\mathrm{mg} / \mathrm{L} \text { range of soluble } \\
\text { organic or inorganic } \\
\text { phosphate }\end{array}$ & $<0.5 \mathrm{mg} / \mathrm{L}$ & $<0.5 \mathrm{mg} / \mathrm{L}$ & $<0.5 \mathrm{mg} / \mathrm{L}$ \\
\hline \begin{tabular}{|l} 
Dissolved \\
Oxygen $\left(\mathrm{O}_{2}\right)$
\end{tabular} & $\begin{array}{l}<1 \mathrm{mg} / \mathrm{L} \\
\text { (Toxic to SRB) }\end{array}$ & $0.654 \mathrm{mg} / \mathrm{L}$ & $0.255 \mathrm{mg} / \mathrm{L}$ & $0.664 \mathrm{mg} / \mathrm{L}$ \\
\hline $\begin{array}{l}\text { Nitrate } \\
\left(\mathrm{NO}_{3}^{-}\right)\end{array}$ & $\begin{array}{l}\text { Small fraction of } \mathrm{SO}_{4} \\
\text { concentration }\end{array}$ & $<0.5 \mathrm{mg} / \mathrm{L}$ & $<0.5 \mathrm{mg} / \mathrm{L}$ & $<0.5 \mathrm{mg} / \mathrm{L}$ \\
\hline $\begin{array}{l}\text { Manganese } \\
\left(\mathrm{Mn}^{+4}\right)^{3}\end{array}$ & $\begin{array}{l}\text { Small fraction of } \mathrm{SO}_{4} \\
\text { concentration }\end{array}$ & $\mathrm{Mn}_{\text {total }}=2.418 \mathrm{mg} / \mathrm{L}$ & $\mathrm{Mn}_{\text {total }}=28.2 \mathrm{mg} / \mathrm{L}$ & $\mathrm{Mn}_{\text {total }}=9.58 \mathrm{mg} / \mathrm{L}$ \\
\hline $\begin{array}{l}\text { Ferric Iron } \\
\left(\mathrm{Fe}^{+3}\right)\end{array}$ & $\begin{array}{l}\text { Small fraction of } \mathrm{SO}_{4} \\
\text { concentration }\end{array}$ & $\begin{array}{l}\mathrm{Fe}_{\text {total }}=252.05 \mathrm{mg} / \mathrm{L} \\
\mathrm{All} \mathrm{Fe}^{+2}\end{array}$ & $\begin{array}{l}\mathrm{Fe}_{\text {total }}=181 \mathrm{mg} / \mathrm{L} \\
\text { Valance not known }\end{array}$ & $\begin{array}{l}\mathrm{Fe}_{\text {total }}=182 \mathrm{mg} / \mathrm{L} \\
\text { All Fe }^{+2}\end{array}$ \\
\hline $\begin{array}{l}\text { Sulfate } \\
\left(\mathrm{SO}_{4}^{-2}\right)\end{array}$ & $\begin{array}{l}\text { Significant } \mathrm{SO}_{4} \\
\text { concentrations; } \\
<170 \mathrm{mg} / \mathrm{L} \mathrm{H}_{2} \mathrm{~S} \text { (higher } \\
\text { concentrations may } \\
\text { inhibit SRB) }\end{array}$ & $\begin{array}{l}\mathrm{SO}_{4}^{-2}=1262 \mathrm{mg} / \mathrm{L} \\
\mathrm{H}_{2} \mathrm{~S}=0.14 \mathrm{mg} / \mathrm{L}\end{array}$ & $\begin{array}{l}\mathrm{SO}_{4}^{-2}=2817.64 \mathrm{mg} / \mathrm{L} \\
\mathrm{H}_{2} \mathrm{~S}=0.228 \mathrm{mg} / \mathrm{L}\end{array}$ & $\begin{array}{l}\mathrm{SO}_{4}^{-2}=15.80 \mathrm{mg} / \mathrm{L} \\
\mathrm{H}_{2} \mathrm{~S}=0.042 \mathrm{mg} / \mathrm{L}\end{array}$ \\
\hline \begin{tabular}{|l|} 
Acetate \\
$\mathrm{CO}_{2}$ \\
$\mathrm{H}_{2}$ \\
\end{tabular} & $\begin{array}{l}\text { Eh > }-150 \mathrm{mV} \\
\text { presence of significant } \\
\text { sulfate }\end{array}$ & $\begin{array}{l}\mathrm{Eh}=224 \mathrm{mV} \\
\mathrm{SO}_{4}^{-2}=1262 \mathrm{mg} / \mathrm{L}\end{array}$ & $\begin{array}{l}\mathrm{Eh}=581 \mathrm{mV} \\
\mathrm{SO}_{4}^{-2}=2817.64 \mathrm{mg} / \mathrm{L}\end{array}$ & $\begin{array}{l}\mathrm{Eh}=129 \mathrm{mV} \\
\mathrm{SO}_{4}^{-2}=15.80 \mathrm{mg} / \mathrm{L}\end{array}$ \\
\hline Aluminum & $\begin{array}{l}\text { Low concentrations } \\
\text { (Toxic to SRB) }\end{array}$ & $0.648 \mathrm{mg} / \mathrm{L}$ & $196 \mathrm{mg} / \mathrm{L}$ & $1.20 \mathrm{mg} / \mathrm{L}$ \\
\hline
\end{tabular}

${ }^{1}$ Sources for optimal sulfate reduction conditions: Benner et al. 1999; Chapelle 1993; EPA 1999; Fauque 1995; Fenchel et al. 1998; Thomas et al. 1999

${ }^{2}$ Turick et al. 2002

${ }^{3}$ Dissolved Mn data may include both ${ }^{+2}$ and ${ }^{+4}$ species; at the $\mathrm{pH}$ and Eh ranges given above, $\mathrm{Mn}^{+2}$ should be the dominant species present.

${ }^{4}$ Preliminary Data - Analysis still on-going

${ }^{5}$ Piezometer within the upgradient side of the DIW-1 north wing

\subsection{CONCLUSIONS}

A re-evaluation of the DTT-1 limestone trench has been conducted to determine if the hydraulic and geochemical activity of the trench is similar to its initial conditions upon installation three 
years ago. Additionally the potential to promote sulfate reduction at the limestone trench with the addition of an organic carbon substrate has been evaluated.

Based upon a comparison of specific capacity measurements the limestone trench appears to be essentially as hydraulically active now as it was at its installation. This indicates that precipitate accumulation has not significantly plugged the limestone or the formation. Additionally based upon analytical results it has been determined that the limestone trench remains an effective treatment for increasing the $\mathrm{pH}$ and removing aluminum both within and downgradient of the trench as at installation. Finally based upon the microbial results it has been determined that the limestone trench has increased microbial activity, including SRBs, both within and downgradient of the trench and has in general improved conditions relative to optimal sulfate reduction conditions from upgradient conditions. In fact the conditions within and downgradient of the trench are better relative to optimal sulfate reduction conditions than that of DIW-1 prior to injection of the soybean oil into it. Therefore the addition of soybean oil at the limestone trench should result in successful sulfate reduction remediation.

Based upon these conclusions the following recommendation are made:

- Since the possibility exists to deactivate the limestone with the injection of soybean oil into the limestone trench, it is recommended that if soybean oil is to be injected at this location it be done downgradient of the trench.

- Over the initial three-year period no significant hydraulic or geochemical degradation of the limestone was observed. However the buildup of aluminum hydroxide precipitates over time may impact the longevity and effectiveness of the limestone trench. Therefore it is recommended that the methods presented in section 4.0 be considered to determine the effects of aluminum hydroxide precipitation on limestone reactivity over longer time periods.

\subsection{REFERENCES}

Benner, S. G., D. W. Blowes, W.D. Gould. R. B. Herbert, Jr. and C. J. Ptacek. 1999.

Geochemistry of a permeable reactive barrier for metals and acid mine drainage. Environmental Science and Technology. 33: 2793-2799.

Chapelle, F. H., 1993, Ground-water microbiology and geochemistry, John Wiley \& Sons, Inc., New York. 
EPA, 1999. Microbial Processes Affecting Monitored Natural Attenuation of Contaminants in the Subsurface, EPA/540/S-99/001, United States Environmental Protection Agency, Washington, DC, September 1999.

Fauque, G. D. 1995. Ecology of sulfate reducing bacteria. pp. 217-235. In. Sulfate-reducing bacteria. (ed) L. L. Barton. Plenum Press. NY, NY.

Fenchel, T., G. M. King and T. H. Blackburn. 1998. In, Bacterial Biogeochemistry: the Ecophysiology of Mineral Cycling. pp 26-28. Academic Press, NY, NY.

Phifer, M. A., Turick, C. E., and Millings, M. R., 2001. D-Area Coal Pile Runoff Basin Sulfate Reduction Literature Review and Feasibility Report (U), WSRC-TR-2001-00371, Revision 0, September 25, Westinghouse Savannah River Company, Savannah River Site, Aiken SC 29808

Phifer, M. A., Sappington, F. C., Millings, M. R., Turick, C. E., and McKinsey, P. C., 2002a. DArea Sulfate Reduction Study Field Scoping Plan (U), Q-TPL-D-00006, May 20, Westinghouse Savannah River Company, Savannah River Site, Aiken SC 29808

Phifer, M. A., Sappington, F. C., Millings, M. R., Turick, C. E., and McKinsey, P. C., 2002b. DArea Treatment Trench (DTT-1) Evaluation Field Scoping Plan (U), Q-TPL-D-00007, October 15, Westinghouse Savannah River Company, Savannah River Site, Aiken SC 29808

Thomas, R. C., Romanek, C. S., Coughlin, D. P., and Crowe, D. E., 1999. “Treatment of Acid Mine Drainage Using Anaerobic Constructed Wetlands: Predicting Longevity with Substrate Neutralization Potential," Proceedings of Sudbury '99 Mining and Environmental II Conference, Sudbury, Ontario, Canada, pages 449-458.

Turick, M. R., McKinsey, P. C., Phifer, M. A., Sappington, F. C., and Millings, 2002. D-Area Sulfate Reduction Study Bacteria Population and Organic Selection Laboratory Testing (U), WSRC-TR-2002-00346, September 20, Westinghouse Savannah River Company, Savannah River Site, Aiken SC 29808

Washburn, F. A., Denham, M. E., Jones, W. E., Phifer, M. A., and Sappington, F. C., 1999. Permeable Reactive Barrier/GeoSiphon Treatment System for Metals Contaminated Groundwater Final Report (U), WSRC-RP-99-01063, November, Westinghouse Savannah River Company, Savannah River Site, Aiken SC 29808

WSRC, 2001. D-Area Coal Pile Runoff Basin Sulfate-Reduction Remediation Treatability Study Work Plan (U), WSRC-RP-2001-00923, Rev. 0, December, Westinghouse Savannah River Company, Savannah River Site, Aiken, SC 29808 
Left Blank Intentionally 


\section{APPENDICES}

Appendix A-1, Flow Measurements.

Appendix A-2, Water Elevations (Determined from Electric Water Level Tape

Measurement)

Appendix B-1, Pre-Pump Field Parameter Profiles...................................................................... 38

Appendix B-2, Field Parameters ........................................................................................................... 40

Appendix B-3, Anions and Cations (EBS Laboratory IC Results) ............................................. 41

Appendix B-4, Metals (SRTC Mobile Laboratory ICP-AES Results) .................................... 42

Appendix B-5, Iron Speciation (SRTC Mobile Laboratory) .................................................. 44

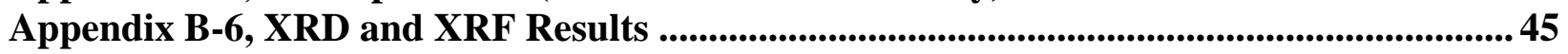

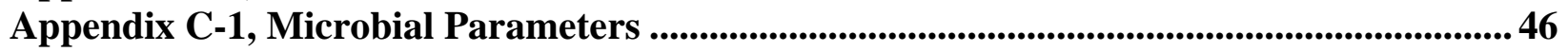




\section{Appendix A-1, Flow Measurements}

\begin{tabular}{|c|c|c|c|c|}
\hline Date/Time & $\begin{array}{c}\text { Cumulative } \\
\text { Duration since } \\
\text { Pumping Began } \\
\text { (min) }\end{array}$ & $\begin{array}{c}\text { Volume Collected } \\
\text { (L) }\end{array}$ & $\begin{array}{c}\text { Collection } \\
\text { Duration } \\
(\mathrm{sec})\end{array}$ & $\begin{array}{l}\text { Flow } \\
(\mathrm{gpm})\end{array}$ \\
\hline 12/9/02 10:14 & 0 & 0 & 0 & 0 \\
\hline 12/9/02 10:15 & 1 & 1.00 & 29.5 & 0.54 \\
\hline 12/9/02 10:30 & 16 & 1.00 & 29.5 & 0.54 \\
\hline 12/9/02 10:35 & 21 & 1.00 & 29.8 & 0.53 \\
\hline 12/9/02 10:45 & 31 & 1.00 & 29.3 & 0.54 \\
\hline 12/9/02 13:05 & 171 & 0.95 & 29.0 & 0.52 \\
\hline 12/9/02 15:04 & 290 & 0.98 & 30.6 & 0.51 \\
\hline 12/9/02 15:15 & 301 & 16.80 & 600 & 0.44 \\
\hline 12/9/02 15:40 & 326 & 16.80 & 505 & 0.53 \\
\hline $12 / 10 / 028: 50$ & 1356 & 16.80 & 632 & 0.42 \\
\hline 12/10/02 9:10 & 1376 & 16.80 & 550 & 0.48 \\
\hline $12 / 10 / 02$ 10:24 & 1450 & 16.80 & 523 & 0.51 \\
\hline 12/11/02 9:45 & 2851 & 16.80 & 809 & 0.33 \\
\hline 12/11/02 10:15 & 2881 & 16.80 & 830 & 0.32 \\
\hline 12/11/02 10:20 & 2886 & 16.80 & 830 & 0.32 \\
\hline 12/11/02 10:21 & 2887 & 0 & 0 & 0 \\
\hline $12 / 16 / 028: 50$ & 0 & 0 & 0 & 0 \\
\hline 12/16/02 8:51 & 1 & 16.80 & 232 & 1.15 \\
\hline 12/16/02 9:03 & 13 & 16.80 & 232 & 1.15 \\
\hline 12/16/02 9:24 & 34 & 16.80 & 225 & 1.19 \\
\hline $12 / 16 / 02$ 11:30 & 160 & 16.80 & 232 & 1.15 \\
\hline 12/16/02 14:41 & 351 & 16.80 & 239 & 1.12 \\
\hline 12/17/02 8:24 & 1414 & 16.80 & 452 & 0.59 \\
\hline 12/17/02 8:40 & 1430 & 16.80 & 237 & 1.13 \\
\hline $12 / 17 / 028: 45$ & 1435 & 16.80 & 238 & 1.12 \\
\hline $12 / 17 / 02$ 15:43 & 1853 & 16.80 & 276 & 0.97 \\
\hline $12 / 17 / 02$ 15:55 & 1865 & 16.80 & 228 & 1.17 \\
\hline 12/18/02 8:04 & 2834 & 16.80 & 277 & 0.96 \\
\hline 12/18/02 8:48 & 2878 & 16.80 & 280 & 0.95 \\
\hline 12/18/02 9:01 & 2891 & 16.80 & 280 & 0.95 \\
\hline 12/18/02 9:02 & 2892 & 16.80 & 0 & 0 \\
\hline
\end{tabular}




\section{Appendix A-2, Water Elevations (Determined from Electric Water Level Tape} Measurement)

\begin{tabular}{|c|c|c|c|c|c|}
\hline $\begin{array}{c}\text { Sample } \\
\text { Location }\end{array}$ & Date/Time & $\begin{array}{l}\text { Top of Casing } \\
\text { (ft-msl) }\end{array}$ & $\begin{array}{c}\text { Depth to Water } \\
\text { (ft) }\end{array}$ & $\begin{array}{c}\text { Water } \\
\text { Elevation } \\
(\mathrm{ft}-\mathrm{msl})\end{array}$ & Phase \\
\hline DCB-49 & $12 / 2 / 0214: 18$ & 124.52 & 7.97 & 116.55 & 1 \\
\hline DCB-49 & 12/5/02 15:09 & 124.52 & 7.78 & 116.74 & 1 \\
\hline DCB-49 & 12/6/02 12:11 & 124.52 & 8.05 & 116.47 & 1 \\
\hline DCB-49 & 12/8/02 9:17 & 124.52 & 7.99 & 116.53 & 1 \\
\hline DCB-49 & 12/9/02 10:06 & 124.52 & 7.98 & 116.54 & 1 \\
\hline DCB-49 & 12/9/02 11:07 & 124.52 & 8.11 & 116.41 & 2 \\
\hline DCB-49 & 12/9/02 15:09 & 124.52 & 8.37 & 116.15 & 2 \\
\hline DCB-49 & 12/10/02 8:43 & 124.52 & 8.68 & 115.84 & 2 \\
\hline DCB-49 & 12/10/02 10:17 & 124.52 & 8.72 & 115.80 & 2 \\
\hline DCB-49 & 12/11/02 9:19 & 124.52 & 8.4 & 116.12 & 2 \\
\hline DCB-49 & 12/11/02 10:11 & 124.52 & 8.43 & 116.09 & 2 \\
\hline DCB-49 & 12/16/02 8:26 & 124.52 & 7.46 & 117.06 & 1 \\
\hline DCB-49 & 12/16/02 11:22 & 124.52 & 7.93 & 116.59 & 3 \\
\hline DCB-49 & $12 / 16 / 0214: 28$ & 124.52 & 8.31 & 116.21 & 3 \\
\hline DCB-49 & 12/17/02 8:12 & 124.52 & 8.64 & 115.88 & 3 \\
\hline DCB-49 & $12 / 17 / 02$ 15:33 & 124.52 & 9.01 & 115.51 & 3 \\
\hline DCB-49 & $12 / 18 / 02$ 7:50 & 124.52 & 9.31 & 115.21 & 3 \\
\hline DCB-49 & 12/18/02 8:58 & 124.52 & 9.36 & 115.16 & 3 \\
\hline DTT-1A & $12 / 2 / 02 \quad 14: 17$ & 124.70 & 8.21 & 116.49 & 1 \\
\hline DTT-1A & $12 / 5 / 02$ 15:05 & 124.70 & 8.03 & 116.67 & 1 \\
\hline DTT-1A & $12 / 6 / 02$ 12:14 & 124.70 & 8.28 & 116.42 & 1 \\
\hline DTT-1A & $12 / 8 / 02$ 9:21 & 124.70 & 8.23 & 116.47 & 1 \\
\hline DTT-1A & 12/9/02 10:06 & 124.70 & 8.23 & 116.47 & 1 \\
\hline DTT-1A & 12/9/02 11:10 & 124.70 & 8.37 & 116.33 & 2 \\
\hline DTT-1A & $12 / 9 / 02$ 15:10 & 124.70 & 8.68 & 116.02 & 2 \\
\hline DTT-1A & 12/10/02 8:44 & 124.70 & 9.06 & 115.64 & 2 \\
\hline DTT-1A & 12/10/02 10:19 & 124.70 & 9.09 & 115.61 & 2 \\
\hline DTT-1A & 12/11/02 9:20 & 124.70 & 8.73 & 115.97 & 2 \\
\hline DTT-1A & 12/11/02 10:09 & 124.70 & 8.75 & 115.95 & 2 \\
\hline DTT-1A & 12/16/02 8:29 & 124.70 & 7.71 & 116.99 & 1 \\
\hline DTT-1A & $12 / 16 / 0211: 24$ & 124.70 & 8.25 & 116.45 & 3 \\
\hline DTT-1A & $12 / 16 / 0214: 29$ & 124.70 & 8.71 & 115.99 & 3 \\
\hline DTT-1A & 12/17/02 8:15 & 124.70 & 9.08 & 115.62 & 3 \\
\hline DTT-1A & $12 / 17 / 02$ 15:34 & 124.70 & 9.49 & 115.21 & 3 \\
\hline DTT-1A & $12 / 18 / 027: 51$ & 124.70 & 9.84 & 114.86 & 3 \\
\hline DTT-1A & $12 / 18 / 028: 56$ & 124.70 & 9.87 & 114.83 & 3 \\
\hline
\end{tabular}




\section{Appendix A-2 (continued)}

\begin{tabular}{|c|c|c|c|c|c|}
\hline $\begin{array}{l}\text { Sample } \\
\text { Location }\end{array}$ & Date/Time & $\begin{array}{l}\text { Top of Casing } \\
\text { (ft-msl) }\end{array}$ & $\begin{array}{c}\text { Depth to Water } \\
(\mathrm{ft})\end{array}$ & $\begin{array}{c}\text { Water } \\
\text { Elevation } \\
\text { (ft-msl) }\end{array}$ & Phase \\
\hline DTT-1 & $12 / 2 / 02 \quad 14: 16$ & 122.64 & 6.16 & 116.48 & 1 \\
\hline DTT-1 & 12/5/02 15:07 & 122.64 & 5.97 & 116.67 & 1 \\
\hline DTT-1 & 12/6/02 12:13 & 122.64 & 6.22 & 116.42 & 1 \\
\hline DTT-1 & 12/8/02 9:19 & 122.64 & 6.18 & 116.46 & 1 \\
\hline DTT-1 & 12/9/02 10:07 & 122.64 & 6.18 & 116.46 & 1 \\
\hline DTT-1 & 12/9/02 11:08 & 122.64 & 6.31 & 116.33 & 2 \\
\hline DTT-1 & 12/9/02 15:09 & 122.64 & 6.61 & 116.03 & 2 \\
\hline DTT-1 & 12/10/02 8:44 & 122.64 & 7.01 & 115.63 & 2 \\
\hline DTT-1 & 12/10/02 10:18 & 122.64 & 7.03 & 115.61 & 2 \\
\hline DTT-1 & 12/11/02 9:18 & 122.64 & 6.68 & 115.96 & 2 \\
\hline DTT-1 & 12/11/02 10:09 & 122.64 & 6.69 & 115.95 & 2 \\
\hline DTT-1 & 12/16/02 8:25 & 122.64 & 5.65 & 116.99 & 1 \\
\hline DTT-1 & 12/16/02 11:23 & 122.64 & 6.2 & 116.44 & 3 \\
\hline DTT-1 & $12 / 16 / 02 \quad 14: 29$ & 122.64 & 6.64 & 116.00 & 3 \\
\hline DTT-1 & 12/17/02 8:14 & 122.64 & 7.02 & 115.62 & 3 \\
\hline DTT-1 & 12/17/02 15:32 & 122.64 & 7.42 & 115.22 & 3 \\
\hline DTT-1 & 12/18/02 7:50 & 122.64 & 7.78 & 114.86 & 3 \\
\hline DTT-1 & 12/18/02 8:54 & 122.64 & 7.81 & 114.83 & 3 \\
\hline DTT-1B & $12 / 2 / 02 \quad 14: 20$ & 124.72 & 8.23 & 116.49 & 1 \\
\hline DTT-1B & $12 / 5 / 02$ 15:10 & 124.72 & 8.03 & 116.69 & 1 \\
\hline DTT-1B & 12/6/02 12:14 & 124.72 & 8.29 & 116.43 & 1 \\
\hline DTT-1B & 12/8/02 9:16 & 124.72 & 8.24 & 116.48 & 1 \\
\hline DTT-1B & 12/9/02 10:05 & 124.72 & 8.25 & 116.47 & 1 \\
\hline DTT-1B & 12/9/02 11:04 & 124.72 & 8.37 & 116.35 & 2 \\
\hline DTT-1B & 12/9/02 15:07 & 124.72 & 8.68 & 116.04 & 2 \\
\hline DTT-1B & 12/10/02 8:42 & 124.72 & 9.07 & 115.65 & 2 \\
\hline DTT-1B & 12/10/02 10:15 & 124.72 & 9.1 & 115.62 & 2 \\
\hline DTT-1B & 12/11/02 9:15 & 124.72 & 8.74 & 115.98 & 2 \\
\hline DTT-1B & 12/11/02 10:07 & 124.72 & 8.76 & 115.96 & 2 \\
\hline DTT-1B & 12/16/02 8:23 & 124.72 & 7.72 & 117.00 & 1 \\
\hline DTT-1B & 12/16/02 11:21 & 124.72 & 8.26 & 116.46 & 3 \\
\hline DTT-1B & $12 / 16 / 02 \quad 14: 27$ & 124.72 & 8.7 & 116.02 & 3 \\
\hline DTT-1B & 12/17/02 8:11 & 124.72 & 9.09 & 115.63 & 3 \\
\hline DTT-1B & 12/17/02 15:31 & 124.72 & 9.49 & 115.23 & 3 \\
\hline DTT-1B & 12/18/02 7:48 & 124.72 & 9.85 & 114.87 & 3 \\
\hline DTT-1B & 12/18/02 8:53 & 124.72 & 9.88 & 114.84 & 3 \\
\hline
\end{tabular}




\section{Appendix A-2 (continued)}

\begin{tabular}{|c|c|c|c|c|c|}
\hline $\begin{array}{l}\text { Sample } \\
\text { Location }\end{array}$ & Date/Time & $\begin{array}{l}\text { Top of Casing } \\
\text { (ft-msl) }\end{array}$ & $\begin{array}{c}\text { Depth to Water } \\
(\mathrm{ft})\end{array}$ & $\begin{array}{c}\text { Water } \\
\text { Elevation } \\
\text { (ft-msl) }\end{array}$ & Phase \\
\hline DCB-50 & $12 / 2 / 0214: 10$ & 124.33 & 8.04 & 116.29 & 1 \\
\hline DCB-50 & 12/5/02 15:08 & 124.33 & 7.86 & 116.47 & 1 \\
\hline DCB-50 & 12/6/02 12:12 & 124.33 & 8.1 & 116.23 & 1 \\
\hline DCB-50 & 12/8/02 9:18 & 124.33 & 8.07 & 116.26 & 1 \\
\hline DCB-50 & 12/9/02 10:05 & 124.33 & 8.06 & 116.27 & 1 \\
\hline DCB-50 & 12/9/02 11:06 & 124.33 & 8.16 & 116.17 & 2 \\
\hline DCB-50 & 12/9/02 15:08 & 124.33 & 8.4 & 115.93 & 2 \\
\hline DCB-50 & 12/10/02 8:43 & 124.33 & 8.71 & 115.62 & 2 \\
\hline DCB-50 & 12/10/02 10:16 & 124.33 & 8.74 & 115.59 & 2 \\
\hline DCB-50 & 12/11/02 9:17 & 124.33 & 8.45 & 115.88 & 2 \\
\hline DCB-50 & 12/11/02 10:08 & 124.33 & 8.45 & 115.88 & 2 \\
\hline DCB-50 & 12/16/02 8:24 & 124.33 & 7.55 & 116.78 & 1 \\
\hline DCB-50 & 12/16/02 11:22 & 124.33 & 7.95 & 116.38 & 3 \\
\hline DCB-50 & 12/16/02 14:28 & 124.33 & 8.30 & 116.03 & 3 \\
\hline DCB-50 & 12/17/02 8:13 & 124.33 & 8.65 & 115.68 & 3 \\
\hline DCB-50 & $12 / 17 / 02$ 15:32 & 124.33 & 8.97 & 115.36 & 3 \\
\hline DCB-50 & 12/18/02 7:49 & 124.33 & 9.26 & 115.07 & 3 \\
\hline DCB-50 & 12/18/02 8:59 & 124.33 & 9.33 & 115.00 & 3 \\
\hline DCB-21A & 12/9/02 13:15 & 128.22 & 10.45 & 117.77 & \\
\hline DCB-21A & 12/10/02 10:31 & 128.22 & 10.44 & 117.78 & \\
\hline DCB-21A & $12 / 11 / 02$ 10:30 & 128.22 & 10.47 & 117.75 & \\
\hline DCB-21A & 12/16/02 11:16 & 128.22 & 9.95 & 118.27 & \\
\hline DCB-21A & 12/17/02 7:58 & 128.22 & 9.99 & 118.23 & \\
\hline DCB-21A & 12/17/02 16:03 & 128.22 & 9.95 & 118.27 & \\
\hline DCB-21A & 12/18/02 7:42 & 128.22 & 10.00 & 118.22 & \\
\hline DCB-24A & 12/9/02 11:13 & 124.17 & 7.91 & 116.26 & \\
\hline DCB-24A & 12/10/02 9:03 & 124.17 & 7.92 & 116.25 & \\
\hline DCB-24A & $12 / 10 / 02$ 10:34 & 124.17 & 7.91 & 116.26 & \\
\hline DCB-24A & 12/11/02 10:24 & 124.17 & 7.68 & 116.49 & \\
\hline DCB-24A & 12/16/02 11:33 & 124.17 & 7.22 & 116.95 & \\
\hline DCB-24A & 12/17/02 8:10 & 124.17 & 7.35 & 116.82 & \\
\hline DCB-24A & $12 / 17 / 02$ 15:36 & 124.17 & 7.39 & 116.78 & \\
\hline DCB-24A & 12/18/02 7:47 & 124.17 & 7.45 & 116.72 & \\
\hline
\end{tabular}

Phase 1 = Pre-pumping; Phase $2=$ First pumping episode $(\sim 0.5 \mathrm{gpm})$; Phase $3=$ second pumping episode ( 1 gpm) 


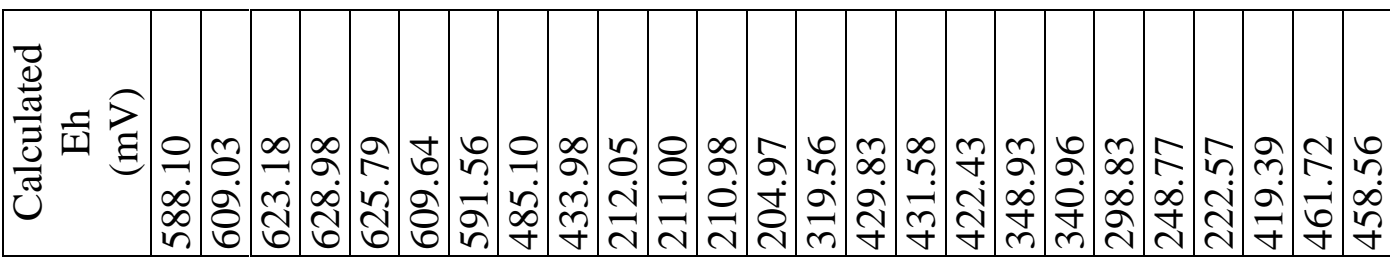

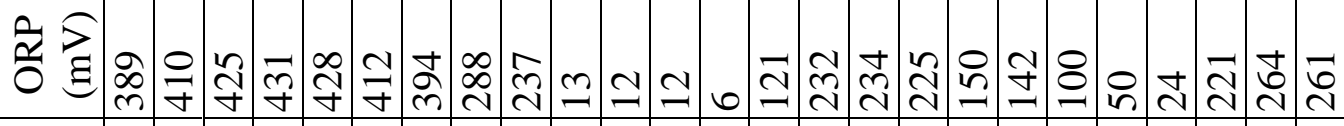

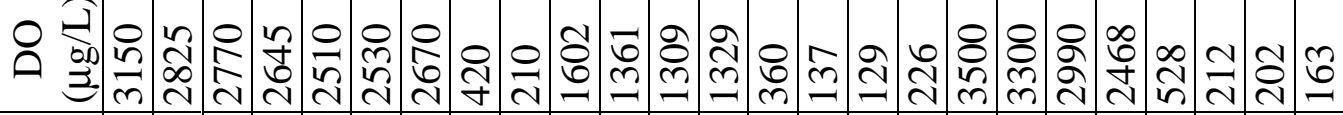
$\stackrel{\nexists}{\ominus}$

:

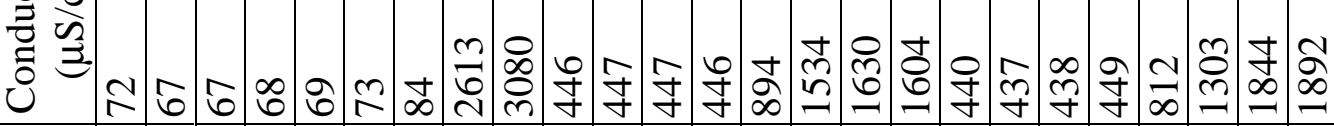

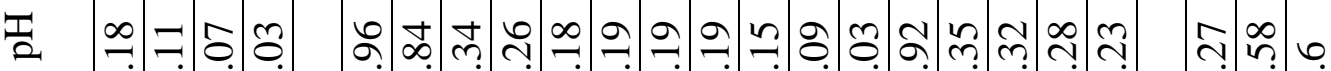
$\stackrel{\circlearrowright}{\leftrightarrows}$

节

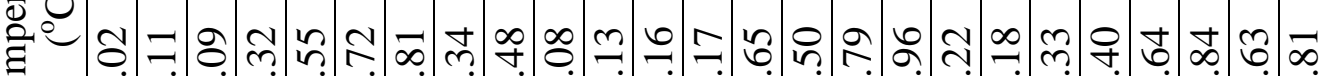
ब

$\stackrel{0}{\exists}$

薷玨

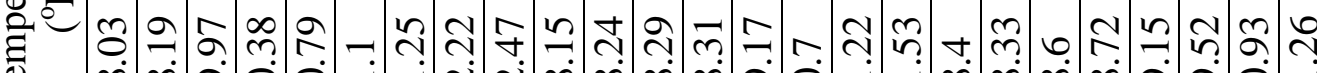

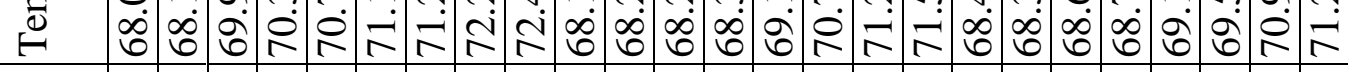

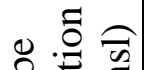

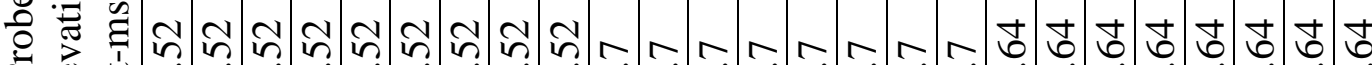

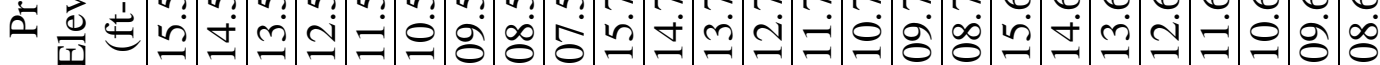

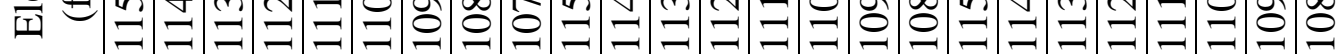

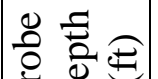

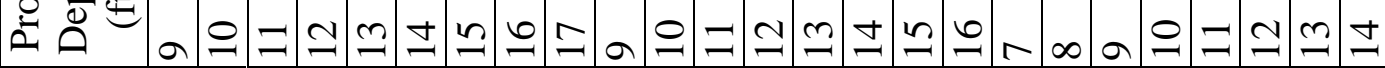

范

की द्व $\Leftrightarrow$ U

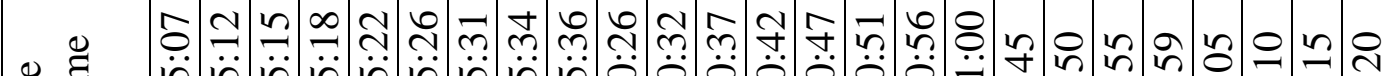

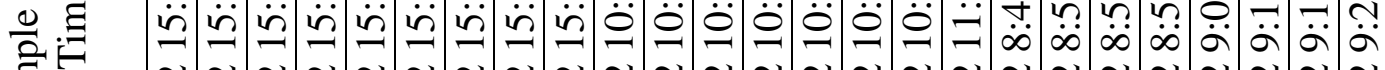
范

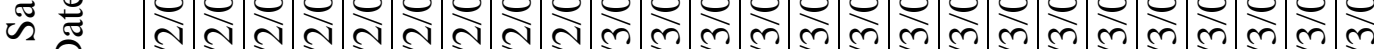

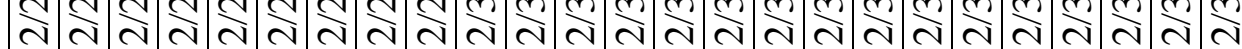

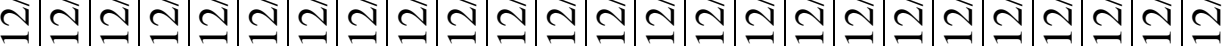

。 


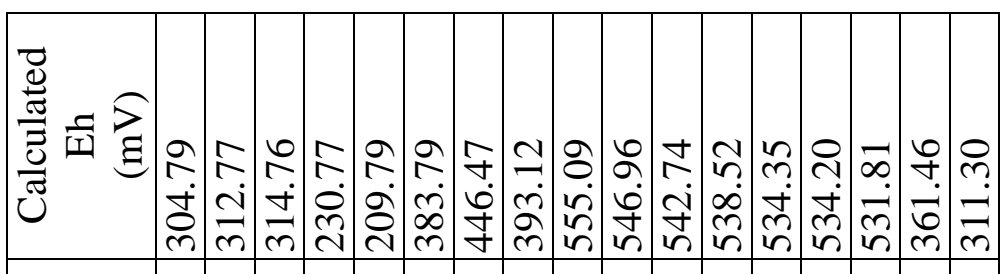
谷

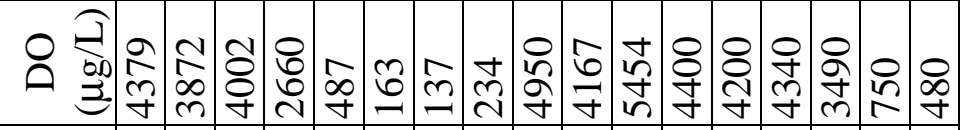
:

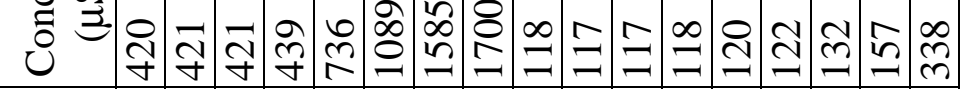

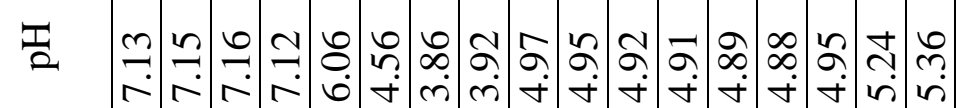
药

范

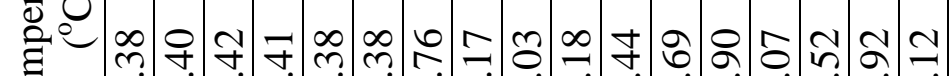
E $\stackrel{0}{3}$

సี.

(I)

吾

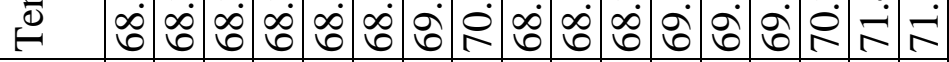
$8 \widetilde{0} \cdot \widetilde{\Xi}$

a ENNNNNNNmmmmmmmmm

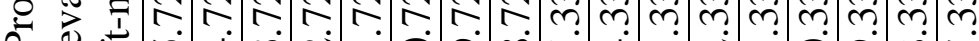

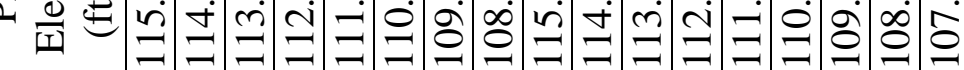

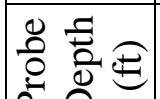

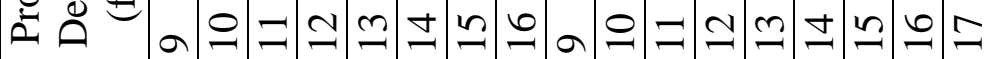

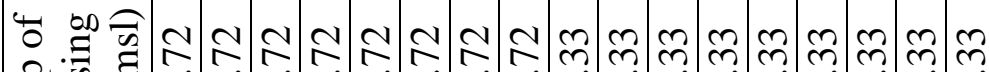
थि

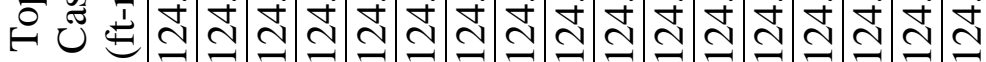
(1)

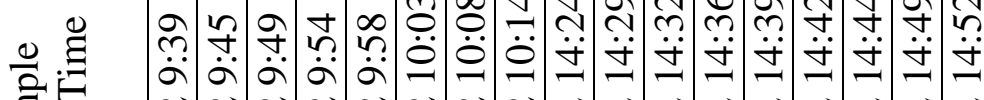

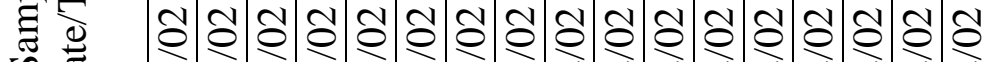

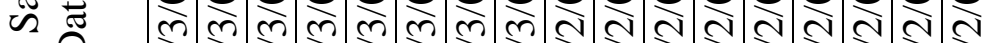
ปิ

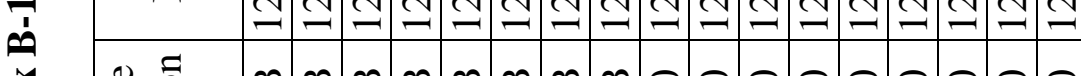
을.

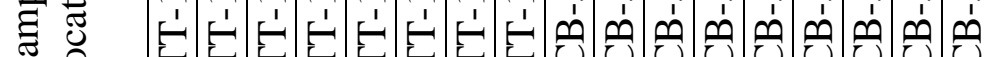

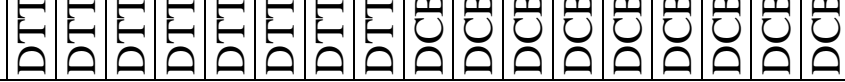




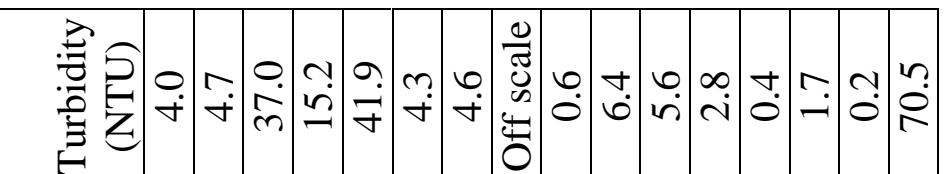
兽 U

วิ)

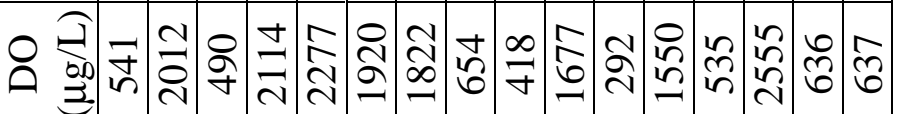

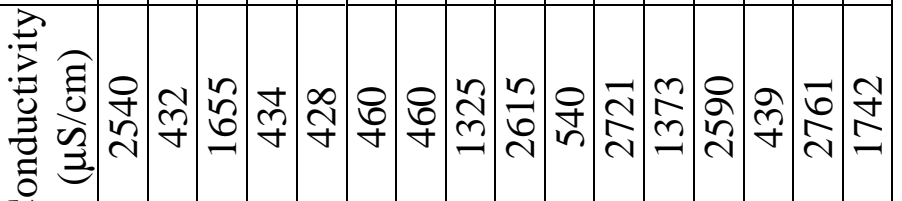
I. 尝

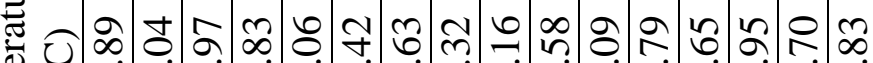

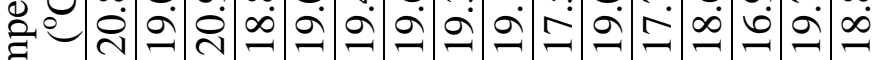
e

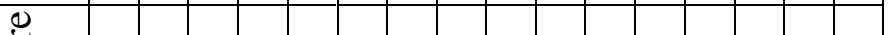
늘

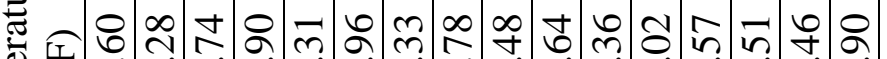
窎

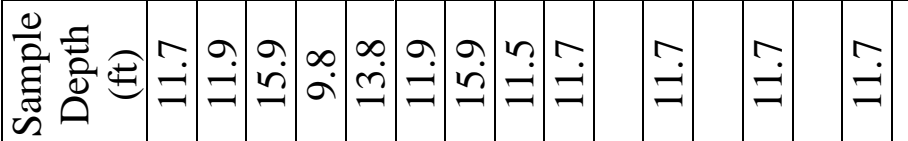
๑

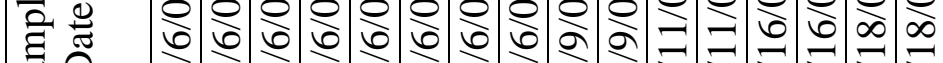
๘ ค

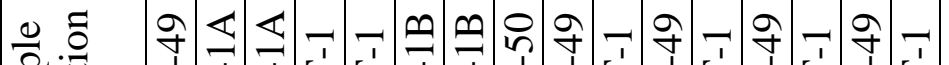
言:

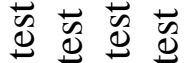
芯芯芯

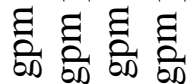

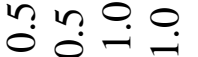
言泀言 bo 000000

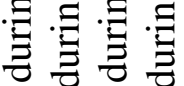

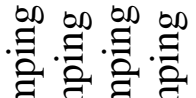
芯志志壳 फै फैँ

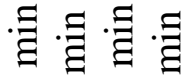
유 유 유

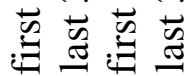

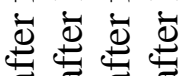

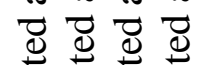
ㄱ ஊ

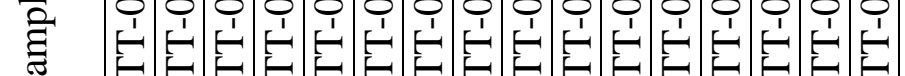

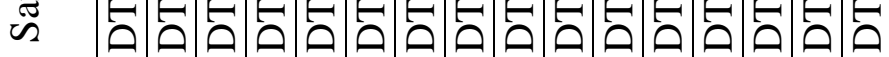
는 $\frac{0}{2} \frac{0}{2}$

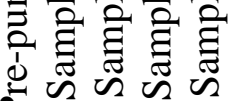

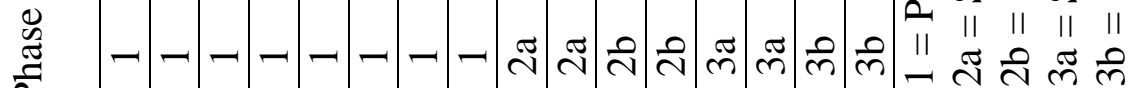




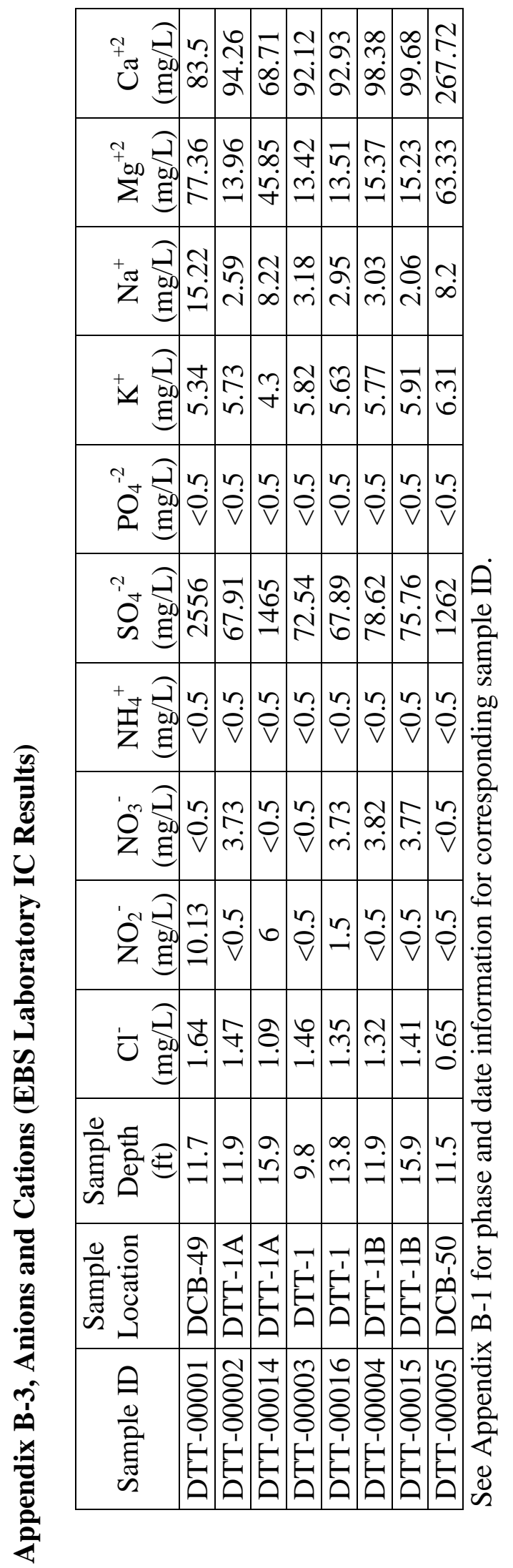




\begin{tabular}{|c|c|c|c|c|c|c|c|c|c|c|c|c|c|c|c|c|}
\hline 它 & 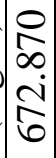 & t) & $\begin{array}{c}8 \\
0 \\
m \\
\dot{N} \\
\\
\end{array}$ & \begin{tabular}{|l|} 
\\
\\
0 \\
$\dot{0}$ \\
$\mathbf{v}$
\end{tabular} & 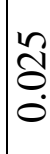 & o & $\begin{array}{l}\dot{\Xi} \\
\dot{8} \\
\dot{V}\end{array}$ & 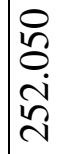 & $\begin{array}{l}0 \\
8 \\
\infty \\
0 \\
0 \\
0\end{array}$ & $\begin{array}{l}\stackrel{0}{0} \\
\text { ? } \\
\text { त }\end{array}$ & 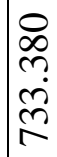 & 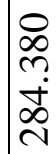 & 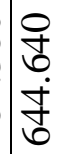 & $\stackrel{n}{\tilde{n}}$ & 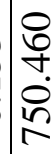 & \\
\hline ت & 是 & 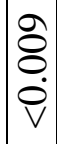 & $\begin{array}{c}n \\
0 \\
\dot{0}\end{array}$ & $\begin{array}{l}8 \\
8 \\
0 \\
\dot{0} \\
\mathbf{v}\end{array}$ & 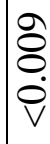 & $\begin{array}{l}\mathscr{8} \\
\stackrel{8}{0} \\
\dot{0} \\
\mathrm{v}\end{array}$ & $\begin{array}{l}\stackrel{g}{8} \\
\dot{\rho} \\
\dot{\gamma}\end{array}$ & $\begin{array}{l}\stackrel{g}{8} \\
\stackrel{0}{0} \\
\dot{\vartheta}\end{array}$ & $\begin{array}{l}0 \\
0 \\
0 \\
0\end{array}$ & $\begin{array}{l}\stackrel{9}{8} \\
\dot{\delta} \\
\dot{\gamma}\end{array}$ & 훙 & $\stackrel{n}{\tilde{0}}$ & $\begin{array}{l}\infty \\
0 \\
0 \\
0\end{array}$ & $\begin{array}{l}\delta \\
\delta \\
\dot{\delta} \\
\dot{\theta}\end{array}$ & $\frac{n}{5}$ & \\
\hline ت & $\begin{array}{l}\mathcal{N} \\
\delta \\
0 \\
0 \\
v\end{array}$ & $\begin{array}{l}\mathcal{O} \\
\delta \\
0 \\
\dot{0} \\
V\end{array}$ & $\begin{array}{c}\text { N } \\
\delta \\
0 \\
0 \\
\mathrm{v}\end{array}$ & $\begin{array}{l}\mathcal{1} \\
\delta \\
0 \\
\dot{0} \\
\mathrm{~V}\end{array}$ & $\begin{array}{l}\mathcal{O} \\
\delta \\
\stackrel{0}{0} \\
\text { V }\end{array}$ & $\begin{array}{l}\mathcal{O} \\
\delta \\
O \\
\\
V\end{array}$ & $\begin{array}{l}\mathcal{O} \\
\delta \\
0 \\
\dot{0} \\
V\end{array}$ & $\begin{array}{l}\mathcal{O} \\
\delta \\
0 \\
0 \\
V\end{array}$ & 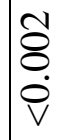 & $\begin{array}{l}\mathcal{O} \\
\delta \\
0 \\
\dot{0} \\
\mathrm{~V}\end{array}$ & $\begin{array}{l}\mathcal{O} \\
\delta \\
0 \\
0 \\
\mathrm{~V}\end{array}$ & $\begin{array}{l}\text { ㄱ. } \\
\delta \\
\stackrel{0}{0} \\
\text { V }\end{array}$ & $\begin{array}{l}\text { ㄱ. } \\
\delta \\
O \\
0 \\
\mathcal{V}\end{array}$ & $\begin{array}{l}\mathcal{O} \\
\delta \\
\mathscr{0} \\
\text { V }\end{array}$ & $\begin{array}{l}\text { N } \\
\delta \\
0 \\
0 \\
V\end{array}$ & \\
\hline 己 & $\begin{array}{l}0 \\
\delta \\
\\
0 \\
\dot{0}\end{array}$ & $\begin{array}{l}0 \\
\delta \\
\dot{\theta} \\
\dot{\theta}\end{array}$ & $\begin{array}{c}0 \\
\delta \\
0 \\
\dot{\delta} \\
v\end{array}$ & $\begin{array}{l}0 \\
\delta \\
\dot{\delta} \\
\dot{v}\end{array}$ & $\begin{array}{l}\hat{\delta} \\
\dot{\delta} \\
\dot{\theta}\end{array}$ & 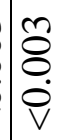 & $\begin{array}{l}\hat{\delta} \\
\dot{\theta} \\
\dot{\theta}\end{array}$ & $\begin{array}{l}\mathscr{8} \\
\stackrel{8}{0} \\
\dot{v}\end{array}$ & $\begin{array}{l}m \\
\delta \\
\dot{\theta} \\
v\end{array}$ & $\begin{array}{l}\hat{\delta} \\
\dot{\delta} \\
\dot{\theta} \\
v\end{array}$ & $\begin{array}{l}\hat{\delta} \\
\dot{\delta} \\
\dot{\theta} \\
v\end{array}$ & $\begin{array}{l}\hat{\delta} \\
\dot{\delta} \\
\dot{\theta} \\
v\end{array}$ & $\begin{array}{l}m \\
\delta \\
\dot{\delta} \\
v\end{array}$ & $\begin{array}{l}\mathcal{O} \\
\stackrel{8}{0} \\
\dot{\theta}\end{array}$ & $\begin{array}{l}m \\
\stackrel{8}{8} \\
\stackrel{0}{v}\end{array}$ & \\
\hline ن & $\begin{array}{l}0 \\
0 \\
\dot{0} \\
\end{array}$ & $\begin{array}{l}2 \\
\infty \\
\infty \\
\infty\end{array}$ & $\begin{array}{l}0 \\
= \\
\overline{0} \\
8\end{array}$ & $\mid \begin{array}{c}0 \\
\stackrel{0}{0} \\
\\
\infty\end{array}$ & 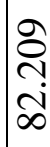 & 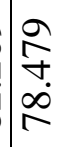 & 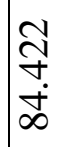 & $\begin{array}{l}8 \\
\stackrel{2}{\infty} \\
\infty \\
\end{array}$ & \begin{tabular}{l}
$\nexists$ \\
\multirow{2}{0}{} \\
$\infty$ \\
0
\end{tabular} & 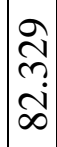 & $\frac{\infty}{\pi}$ & 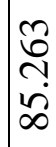 & $\begin{array}{l}\hat{\infty} \\
0 \\
i \\
r\end{array}$ & $\begin{array}{l}0 \\
\infty \\
\infty \\
\infty \\
\infty\end{array}$ & $\begin{array}{l}8 \\
8 \\
\dot{8}\end{array}$ & \\
\hline$\stackrel{\overbrace{}}{\ominus}$ & $\begin{array}{l}n \\
\delta \\
\dot{0} \\
v\end{array}$ & $\begin{array}{l}\mathscr{8} \\
\dot{\delta} \\
\dot{0}\end{array}$ & 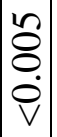 & $\begin{array}{l}n \\
\delta \\
\dot{0} \\
\mathbf{v}\end{array}$ & 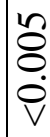 & 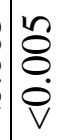 & $\begin{array}{l}n \\
\delta \\
0 \\
\dot{8}\end{array}$ & $\begin{array}{l}n \\
\delta \\
\dot{8} \\
v\end{array}$ & $\begin{array}{l}n \\
\delta \\
\dot{8} \\
v\end{array}$ & 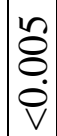 & $\begin{array}{l}n \\
\delta \\
0 \\
\dot{8}\end{array}$ & $\begin{array}{l}n \\
8 \\
0 \\
\dot{8}\end{array}$ & $\begin{array}{l}\mathscr{8} \\
\dot{\delta} \\
\dot{\rho} \\
v\end{array}$ & $\begin{array}{l}\qquad \\
\delta \\
\delta \\
\dot{\delta} \\
v\end{array}$ & $\begin{array}{l}\qquad \\
\delta \\
\dot{\delta} \\
v\end{array}$ & \\
\hline Ф & $\begin{array}{l}\bar{\delta} \\
\dot{0} \\
\overline{0}\end{array}$ & $\begin{array}{l}\bar{\delta} \\
\dot{0} \\
\dot{0}\end{array}$ & 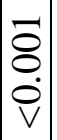 & $\begin{array}{l}\bar{\delta} \\
\dot{\delta} \\
\dot{0}\end{array}$ & $\begin{array}{l}\bar{\delta} \\
\dot{\delta} \\
\dot{0}\end{array}$ & $\begin{array}{l}\overline{8} \\
\dot{8} \\
\dot{8}\end{array}$ & $\begin{array}{l}\bar{\delta} \\
\dot{8} \\
\dot{0}\end{array}$ & $\begin{array}{l}\bar{\delta} \\
\dot{8} \\
\dot{0}\end{array}$ & $\begin{array}{l}\bar{\delta} \\
\dot{8} \\
\dot{0}\end{array}$ & $\begin{array}{l}\bar{\delta} \\
\dot{0} \\
\dot{0}\end{array}$ & $\begin{array}{l}\bar{\delta} \\
\dot{8} \\
\dot{0}\end{array}$ & $\begin{array}{l}\bar{\delta} \\
\dot{8} \\
\dot{0}\end{array}$ & $\begin{array}{l}\bar{\delta} \\
\dot{8} \\
\dot{0}\end{array}$ & $\begin{array}{l}\bar{\delta} \\
\dot{\delta} \\
\dot{0}\end{array}$ & $\begin{array}{l}\bar{\delta} \\
\dot{8} \\
\mathbf{v}\end{array}$ & ? \\
\hline 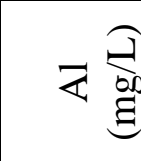 & $\begin{array}{l}0 \\
n \\
n \\
\infty \\
\text { d. } \\
\end{array}$ & ڤ̊ & $\begin{array}{l}0 \\
\tilde{n} \\
2 \\
2\end{array}$ & 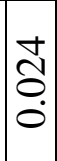 & Г̊ & $\frac{0}{\sigma}$ & 足 & \begin{tabular}{l}
$\infty$ \\
\multirow{0}{0}{} \\
0
\end{tabular} & 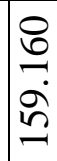 & $\begin{array}{l}\text { 寸 } \\
\text { ச }\end{array}$ & 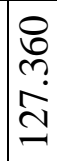 & $\frac{\overline{0}}{0}$ & $\begin{array}{l}8 \\
\infty \\
\infty \\
\\
\end{array}$ & â. & $\begin{array}{l}\text { 워 } \\
\text { à } \\
\text { ป̂. }\end{array}$ & \\
\hline 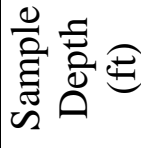 & $\Xi$ & $\stackrel{9}{=}$ & $\left.\begin{array}{c}a \\
n \\
1\end{array}\right]$ & $\begin{array}{l}\infty \\
\sigma^{\prime}\end{array}$ & $\begin{array}{l}\infty \\
\dot{m}\end{array}$ & $\Xi$ & $\stackrel{a}{\check{c}}$ & $\stackrel{n}{\beth}$ & 三 & & 三 & & $\Xi$ & & $\Xi$ & \\
\hline 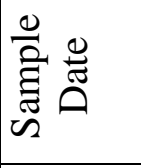 & 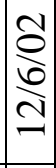 & 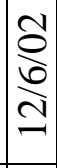 & $\begin{array}{l}\text { va } \\
\text { } \\
\text { ป̂ } \\
-\end{array}$ & 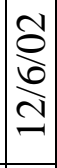 & 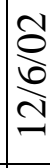 & 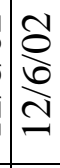 & 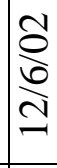 & $\frac{\mathfrak{d}}{\delta}$ & $\frac{\mathfrak{d}}{2}$ & $\frac{\mathfrak{d}}{\grave{d}}$ & $\begin{array}{l}\mathfrak{N} \\
\stackrel{\Xi}{\Xi} \\
\end{array}$ & 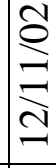 & 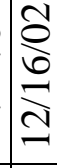 & 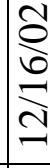 & 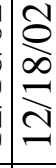 & 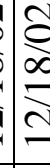 \\
\hline 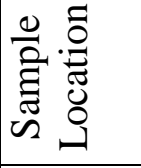 & 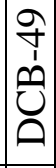 & 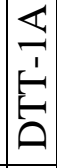 & 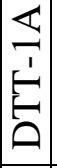 & 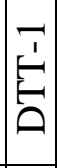 & $\stackrel{ت}{\stackrel{1}{E}}$ & 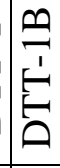 & 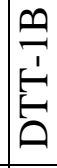 & $\begin{array}{l}0 \\
n \\
0 \\
0\end{array}$ & $\begin{array}{l}a \\
\dot{y} \\
\varrho \\
\varrho\end{array}$ & صـ & $\begin{array}{l}0 \\
\dot{y} \\
0 \\
\tilde{y}\end{array}$ & 告 & 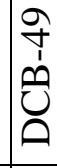 & 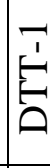 & ص̧ & 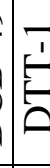 \\
\hline 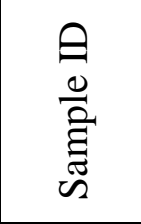 & $\begin{array}{l}\overline{8} \\
8 \\
8 \\
0 \\
1 \\
0 \\
0 \\
0\end{array}$ & 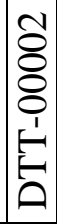 & 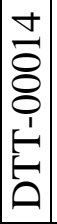 & 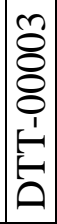 & $\begin{array}{l}0 \\
0 \\
8 \\
8 \\
0 \\
1 \\
= \\
0 \\
0\end{array}$ & 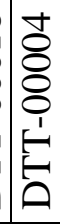 & $\begin{array}{l}n \\
8 \\
8 \\
0 \\
1 \\
\\
0\end{array}$ & 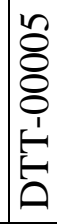 & 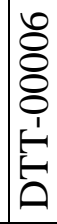 & $\begin{array}{l}\hat{8} \\
8 \\
8 \\
0 \\
1 \\
\\
0\end{array}$ & 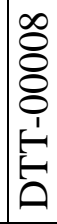 & $\begin{array}{l}8 \\
8 \\
8 \\
8 \\
0 \\
1 \\
\\
1 \\
0\end{array}$ & $\begin{array}{l}0 \\
\overline{8} \\
8 \\
0 \\
1 \\
\underline{\underline{\prime}} \\
0\end{array}$ & $\begin{array}{l}= \\
\\
8 \\
0 \\
1 \\
1 \\
1 \\
1 \\
0\end{array}$ & 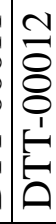 & 吾 \\
\hline 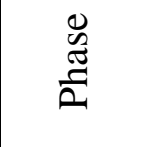 & - & - & -1 & -7 & - & $1-$ & - & - & $\widetilde{N}$ & $\sim$ & ते & $\vec{N}$ & $\stackrel{\pi}{\sim}$ & $m$ & $\bar{m}$ & $m$ \\
\hline
\end{tabular}




\begin{tabular}{|c|c|c|c|c|c|c|c|c|c|c|c|c|c|c|c|c|}
\hline 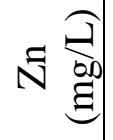 & $\begin{array}{l}0 \\
8 \\
0 \\
i\end{array}$ & $\begin{array}{l}\bar{\delta} \\
0 \\
0 \\
\dot{0}\end{array}$ & $\stackrel{\infty}{\frac{\infty}{\sigma}}$ & 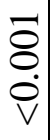 & $\begin{array}{l}\overline{0} \\
8 \\
0 \\
0 \\
v\end{array}$ & $\begin{array}{l}\bar{\sigma} \\
\dot{8} \\
\dot{v}\end{array}$ & $\begin{array}{l}\overline{8} \\
\dot{0} \\
\dot{0}\end{array}$ & $\begin{array}{l}0 \\
\text { t. } \\
\vdots \\
0\end{array}$ & $\left|\begin{array}{c}1 \\
8 \\
\swarrow \\
-\end{array}\right|$ & $\mid \begin{array}{l}\overline{0} \\
\dot{8} \\
\dot{0} \\
\mathbf{v}\end{array}$ & $\begin{array}{c}\frac{1}{J} \\
\stackrel{i}{i}\end{array}$ & $\begin{array}{l}\tilde{J} \\
\tilde{0} \\
0\end{array}$ & $\begin{array}{l}\mathcal{N} \\
\infty \\
\vdots \\
i\end{array}$ & $\begin{array}{l}\overline{8} \\
\dot{8} \\
\dot{0} \\
\mathrm{v}\end{array}$ & $\begin{array}{l}0 \\
8 \\
\text { i } \\
\text { in }\end{array}$ & 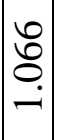 \\
\hline is $\begin{array}{l}\stackrel{\theta}{b 0} \\
\Xi\end{array}$ & $\begin{array}{l}0 \\
\tilde{n} \\
0 \\
0 \\
n\end{array}$ & $\underset{乛}{F}$ & $\begin{array}{c}\infty \\
i \\
n \\
m \\
\gamma\end{array}$ & 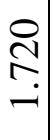 & 吉 & $\begin{array}{l}6 \\
\infty \\
\infty \\
-\end{array}$ & \begin{tabular}{l}
2 \\
\multirow{-}{*}{} \\
-
\end{tabular} & 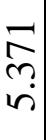 & 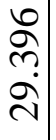 & 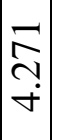 & $\begin{array}{l}\hat{\sigma} \\
\text { rá } \\
\text { m. }\end{array}$ & $\begin{array}{l}\mathcal{N} \\
\dot{J} \\
\dot{J}\end{array}$ & $\begin{array}{l}\text { ป̂ } \\
\text { กุ } \\
\text { ปิ }\end{array}$ & 字. & 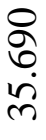 & $\mid \begin{array}{l}n \\
6 \\
n \\
n \\
n\end{array}$ \\
\hline 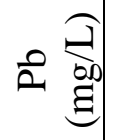 & 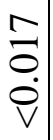 & 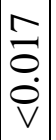 & 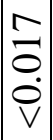 & 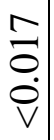 & $\begin{array}{l}\text { T. } \\
\\
0 \\
\dot{0}\end{array}$ & 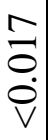 & $\begin{array}{l}\bar{D} \\
0 \\
\dot{0} \\
v\end{array}$ & $\begin{array}{l}\hat{D} \\
0 \\
0 \\
\dot{0} \\
v\end{array}$ & $\begin{array}{l}\bar{\partial} \\
\\
0 \\
\dot{0}\end{array}$ & $\begin{array}{c}\hat{D} \\
\\
0 \\
\dot{0} \\
v\end{array}$ & 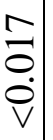 & $\begin{array}{l}\bar{D} \\
0 \\
\dot{0} \\
v\end{array}$ & $\begin{array}{l}\bar{\partial} \\
\\
\dot{0} \\
v\end{array}$ & $\begin{array}{l}\bar{\sigma} \\
0 \\
\dot{0} \\
v\end{array}$ & $\begin{array}{l}\overline{0} \\
0 \\
0 \\
0\end{array}$ & 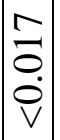 \\
\hline 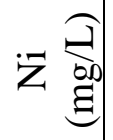 & & $\begin{array}{c}0 \\
\\
0 \\
\dot{0} \\
v\end{array}$ & 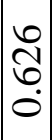 & $\begin{array}{c}0 \\
\\
0 \\
\dot{0} \\
v\end{array}$ & $\begin{array}{c}0 \\
\\
0 \\
\dot{0} \\
v\end{array}$ & $\begin{array}{l}0 \\
\\
0 \\
\dot{0} \\
v\end{array}$ & $\begin{array}{l}0 \\
0 \\
0 \\
0 \\
\dot{v}\end{array}$ & 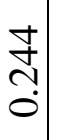 & $\begin{array}{l} \pm \\
\infty \\
0 \\
0\end{array}$ & $\mid \begin{array}{c}0 \\
0 \\
0 \\
\dot{0} \\
v\end{array}$ & $\begin{array}{l}\infty \\
0 \\
0\end{array}$ & $\begin{array}{l}\tilde{f} \\
\dot{0}\end{array}$ & $\begin{array}{l}\infty \\
0 \\
0\end{array}$ & $\begin{array}{l}0 \\
0 \\
0 \\
\dot{0} \\
v\end{array}$ & $\begin{array}{l}\infty \\
2 \\
\infty \\
\infty \\
0\end{array}$ & 文 \\
\hline
\end{tabular}

z

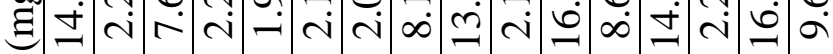

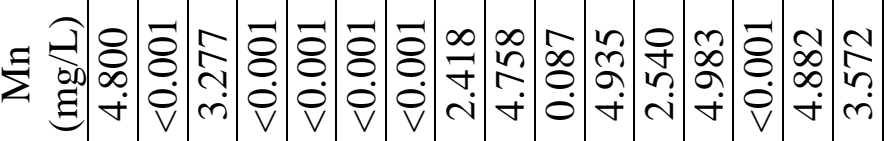

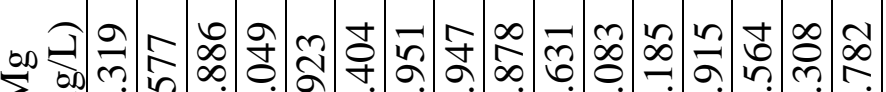

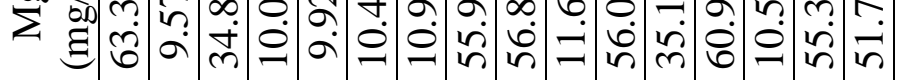

\begin{tabular}{|c|c|c|c|c|c|c|c|c|c|c|c|c|}
\hline 胥 & $三$ & 9 & $\begin{array}{l}0 \\
\text { in }\end{array}$ & $a_{0}^{\infty}$ & $\stackrel{\alpha}{\alpha}$ & $\frac{\sigma}{2}$ & $\begin{array}{l}0 \\
n\end{array}$ & $\because$ & $\Xi$ & $\Xi$ & $\Xi$ & $\exists$ \\
\hline
\end{tabular}

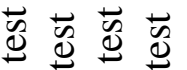

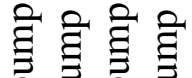

艺芑芑

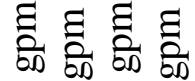

ก. n 0 .

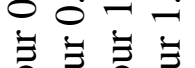

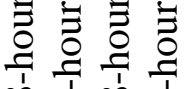

$\stackrel{+\infty}{\infty} \infty$

00 00 00 00

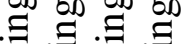

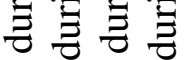

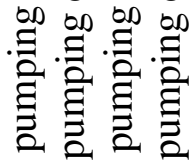

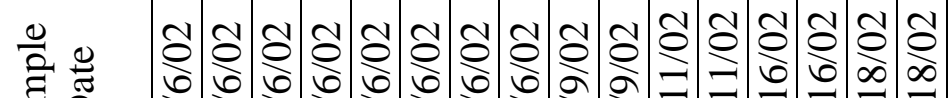

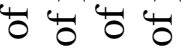

浔浔

응ำ 요

응

芯芯芯芯

言 嵒

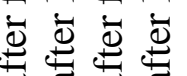

-

-

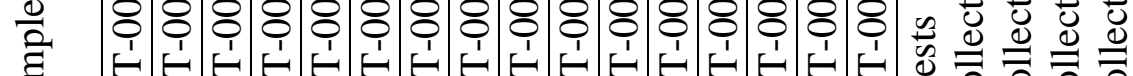

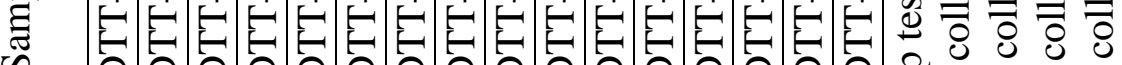

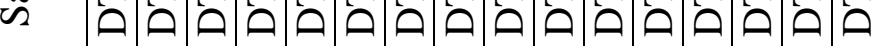

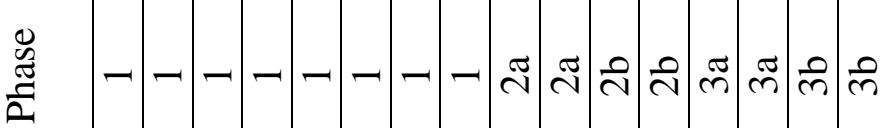

$\Xi \frac{0}{2} \frac{0}{2} \frac{0}{2}$

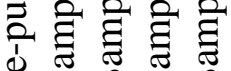




\section{Appendix B-5, Iron Speciation (SRTC Mobile Laboratory)}

\begin{tabular}{|c|c|c|c|c|c|}
\hline Sample ID & Well & $\mathrm{Fe}^{+2}$ & $\mathrm{Fe}^{+3}$ & $\mathrm{Fe}_{\text {total }}$ & $\mathrm{Fe}^{+2} / \mathrm{Fe}_{\text {total }}$ \\
\hline \multirow{2}{*}{ DTT-00001 } & \multirow{2}{*}{ DCB-49 } & 1.515 & $<0.010$ & 1.523 & \multirow{2}{*}{ all $\mathrm{Fe}^{+2}$} \\
\hline & & 1.515 & $<0.010$ & 1.521 & \\
\hline \multirow{2}{*}{ DTT-00002 } & \multirow{2}{*}{ DTT-1A } & $<0.010$ & $<0.010$ & $<0.010$ & \multirow{2}{*}{ no iron detected } \\
\hline & & $<0.010$ & $<0.010$ & $<0.010$ & \\
\hline \multirow{2}{*}{ DTT-00014 } & \multirow{2}{*}{ DTT-1A } & 0.873 & $<0.010$ & 0.877 & \multirow{2}{*}{ all $\mathrm{Fe}^{+2}$} \\
\hline & & 0.876 & $<0.010$ & 0.875 & \\
\hline \multirow{2}{*}{ DTT-00003 } & \multirow{2}{*}{ DTT-1 } & $<0.010$ & $<0.010$ & $<0.010$ & \multirow{2}{*}{ no iron detected } \\
\hline & & $<0.010$ & $<0.010$ & $<0.010$ & \\
\hline \multirow{2}{*}{ DTT-00016 } & \multirow{2}{*}{ DTT-1 } & $<0.010$ & $<0.010$ & $<0.010$ & \multirow{2}{*}{ no iron detected } \\
\hline & & $<0.010$ & $<0.010$ & $<0.010$ & \\
\hline \multirow{2}{*}{ DTT-00004 } & \multirow{2}{*}{ DTT-1B } & $<0.010$ & $<0.010$ & $<0.010$ & \multirow{2}{*}{ no iron detected } \\
\hline & & $<0.010$ & $<0.010$ & $<0.010$ & \\
\hline \multirow{2}{*}{ DTT-00015 } & \multirow{2}{*}{ DTT-1B } & $<0.010$ & $<0.010$ & $<0.010$ & \multirow{2}{*}{ no iron detected } \\
\hline & & $<0.010$ & $<0.010$ & $<0.010$ & \\
\hline \multirow{2}{*}{ DTT-00005 } & \multirow{2}{*}{ DCB-50 } & 0.544 & $<0.010$ & 0.545 & \multirow{2}{*}{ all $\mathrm{Fe}^{+2}$} \\
\hline & & 0.545 & $<0.010$ & 0.545 & \\
\hline \multirow{2}{*}{ DTT-00006 } & \multirow{2}{*}{ DCB-49 } & 1.572 & $<0.010$ & 1.572 & \multirow{2}{*}{ all $\mathrm{Fe}^{+2}$} \\
\hline & & 1.579 & $<0.010$ & 1.582 & \\
\hline \multirow{2}{*}{ DTT-00007 } & \multirow{2}{*}{ DTT-1 } & 0.016 & $<0.010$ & 0.023 & \multirow{2}{*}{ all $\mathrm{Fe}^{+2}$} \\
\hline & & 0.017 & $<0.010$ & 0.024 & \\
\hline DTT_00008 & DCR-49 & 1.593 & $<0.010$ & 1.59 & all $\mathrm{Fe}^{+2}$ \\
\hline $011-00008$ & DСВ-49 & 1.622 & $<0.010$ & 1.624 & all Fe \\
\hline & & 0.629 & $<0.010$ & 0.631 & all $\mathrm{Fe}^{+2}$ \\
\hline D11-00009 & D11-1 & 0.643 & $<0.010$ & 0.639 & \\
\hline DTT_00010 & DCR-49 & 1.365 & $<0.010$ & 1.377 & all $\mathrm{Fe}^{+2}$ \\
\hline D11-00010 & DCB-49 & 1.397 & $<0.010$ & 1.389 & all Fe \\
\hline DTT_-00011 & DTT_-1 & $<0.010$ & $<0.010$ & $<0.010$ & no iron detected \\
\hline $011-00011$ & D11-1 & $<0.010$ & $<0.010$ & $<0.010$ & no iron detected \\
\hline & & 1.622 & $<0.010$ & 1.626 & $11 \mathrm{Fe}^{+2}$ \\
\hline $011-00012$ & DCB-49 & 1.653 & $<0.010$ & 1.660 & all Fe \\
\hline DTT_ 0001 & DTT & 0.718 & $<0.010$ & 0.710 & $\mathrm{Fe}^{+2}$ \\
\hline D11-00015 & D11-1 & 0.712 & $<0.010$ & 0.713 & \\
\hline
\end{tabular}

See Appendix B-3 for phase and date information for corresponding sample ID. 


\section{Appendix B-6, XRD and XRF Results}

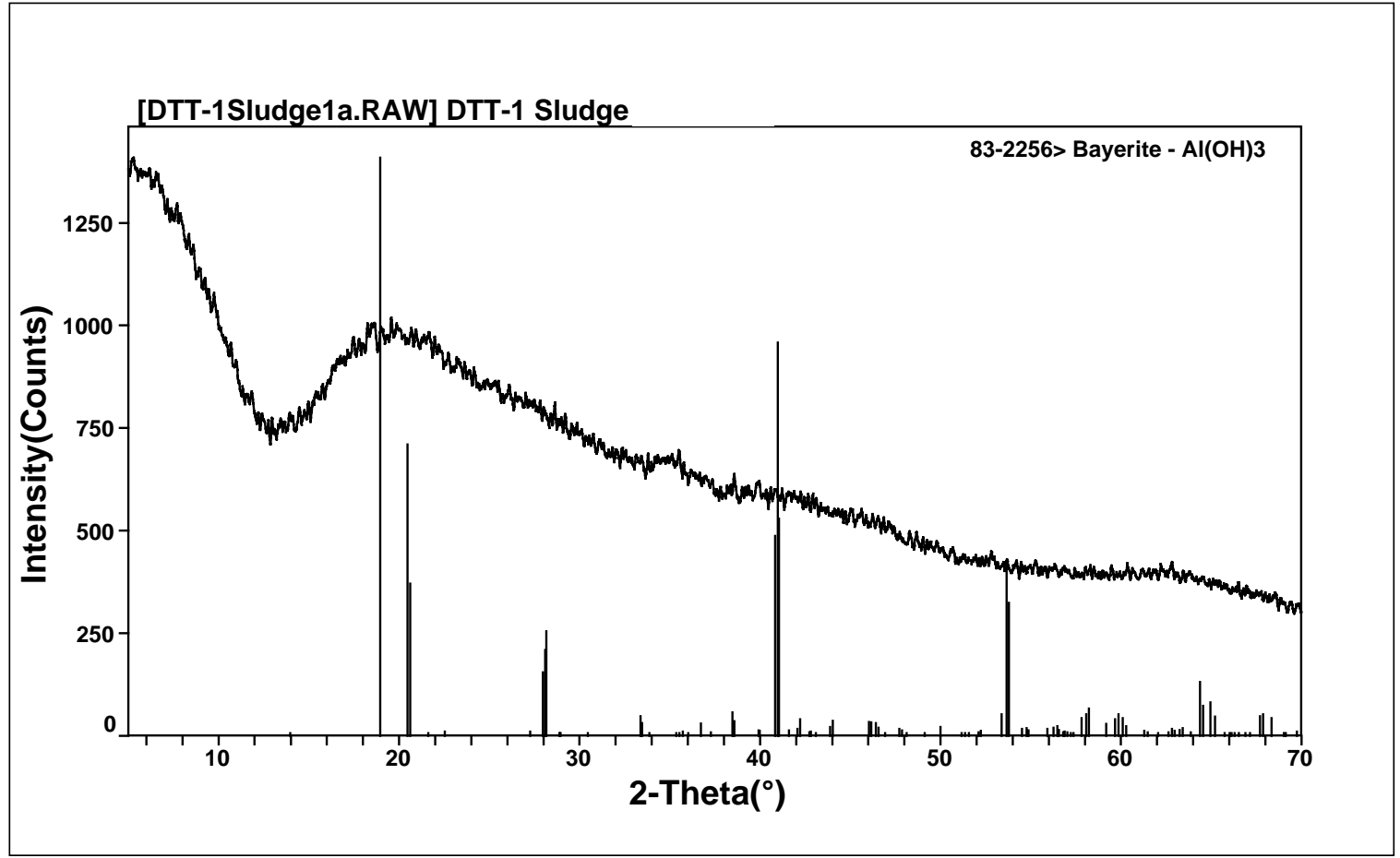

XRD Results: Peaks in the X-ray diffraction spectrum suggest that the sludge is composed of an amorphous aluminum hydroxide mineral (similar to bayerite).

\section{XRF Results:}

\begin{tabular}{|c|c|c|c|c|c|c|c|c|}
\hline $\begin{array}{c}\mathrm{SiO}_{2} \\
\mathrm{wt} \%\end{array}$ & $\begin{array}{c}\mathrm{Al}_{2} \mathrm{O}_{3} \\
\mathrm{wt} \%\end{array}$ & $\begin{array}{c}\mathrm{Fe}_{2} \mathrm{O}_{3} \\
\mathrm{wt} \%\end{array}$ & $\begin{array}{c}\mathrm{MgO} \\
\mathrm{wt} \%\end{array}$ & $\begin{array}{c}\mathrm{CaO} \\
\mathrm{wt} \%\end{array}$ & $\begin{array}{c}\mathrm{Na}_{2} \mathrm{O} \\
\mathrm{wt} \%\end{array}$ & $\begin{array}{c}\mathrm{K}_{2} \mathrm{O} \\
\mathrm{wt} \%\end{array}$ & $\begin{array}{c}\mathrm{P}_{2} \mathrm{O}_{5} \\
\mathrm{wt} \%\end{array}$ & $\begin{array}{c}\mathrm{LOI} \\
\mathrm{wt} \%\end{array}$ \\
\hline 8.47 & 53.15 & 4.89 & 0.47 & 3.32 & 0.01 & 0.09 & 0.38 & 29.15 \\
\hline
\end{tabular}

$\mathrm{LOI}=$ loss on ignition (reflecting loss of water or other volatile componenets)

X-ray fluorescence on another similar sludge sample also indicates that the sludge consists predominantly of aluminum. 


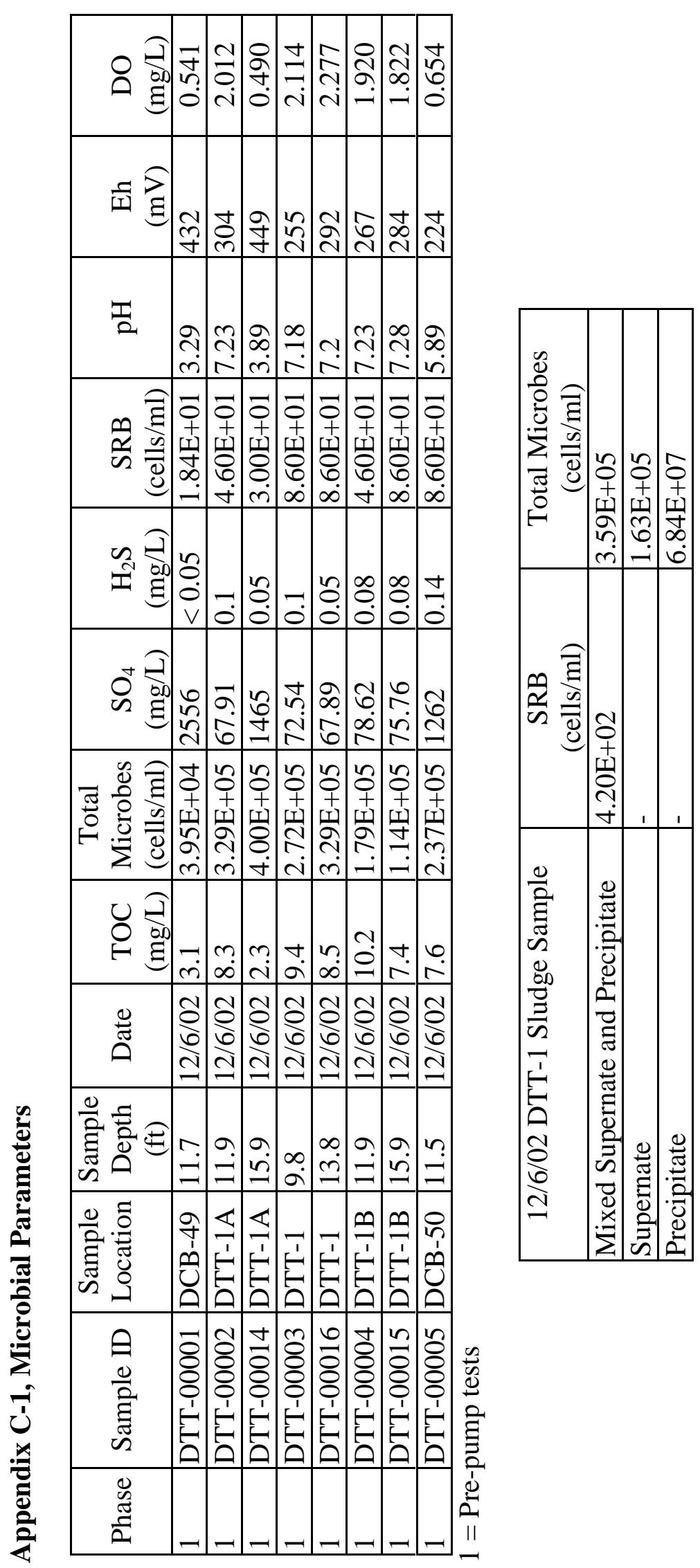

